by Paolo Mietto ${ }^{l}$, Stefano Manfrin ${ }^{l}$, Nereo Preto ${ }^{l}$, Manuel Rigo ${ }^{l, 2}$, Guido Roghi ${ }^{2}$, Stefano Furin ${ }^{3}$, Piero Gianolla ${ }^{3}$, Renato Posenato ${ }^{3}$, Giovanni Muttoni ${ }^{4}$, Alda Nicora ${ }^{4}$, Nicoletta Buratti $^{5}$, Simonetta Cirilli ${ }^{5}$, Christoph Spötl ${ }^{6}$, Jahandar Ramezani ${ }^{7}$, and Samuel A. Bowring ${ }^{7}$

\title{
The Global Boundary Stratotype Section and Point (GSSP) of the Carnian Stage (Late Triassic) at Prati di Stuores/Stuores Wiesen Section (Southern Alps, NE Italy)
}

\author{
${ }^{1}$ Università degli studi di Padova, Dipartimento di Geoscienze, via Gradenigo 6, I-35131 Padova. E-mail:paolo.mietto@unipd.it \\ ${ }^{2}$ C.N.R., Istituto di Geoscienze e Georisorse, via Gradenigo 6, I-35131 Padova \\ ${ }^{3}$ Università degi studi di Ferrara, Dipartimento di Scienze della Terra, via Saragat 1, Blocco B, I-44100, Ferrara \\ ${ }^{4}$ Università degli studi di Milano, Dipartimento di Scienze della Terra, via Mangiagalli 34, I-20133 Milano \\ ${ }^{5}$ Università degli studi di Perugia, Dipartimento di Scienze della Terra, Piazza dell’Università 1, I-06123 Perugia \\ ${ }^{6}$ Institut für Geologie und Paläontologie, Universität Innsbruck, Innrain 52, A-6020 Innsbruck \\ ${ }^{7}$ MIT, 77 Massachusetts Avenue, Cambridge, Massachusetts 02139, USA
}

The Global boundary Stratotype Section and Point (GSSP) for the base of the Carnian Stage (Late Triassic) is defined on the north flank of the Cordevole Valley, on the southern slopes of the crest separating the Badia/Abtei and the Cordevole valleys $\left(46^{\circ} 31^{\prime} 37^{\prime \prime} \mathrm{N}\right.$, $\left.11^{\circ} 55^{\prime} 49^{\prime \prime} \mathrm{E}\right)$ at an elevation of $1980 \mathrm{~m}$, approximately $4.7 \mathrm{~km}$ south of San Cassiano/St. Kassian in the Dolomites (Southern Alps). The Prati di Stuores/Stuores Wiesen section (Province of Belluno, Veneto Region, Italy) is located a few hundred meters east of Pralongià, a locality northeast of Arabba (Belluno). The section consists of hemipelagites and thin turbidite beds (both siliciclastic and carbonate intraclastic), deposited below storm wave-base with a high but variable sediment accumulation rate (San Cassiano Fm.). The GSSP boundary is located at the base of bed SW4, $45 \mathrm{~m}$ above the base of the San Cassiano Fm. Bed SW4 yielded ammonoids including Daxatina canadensis (Whiteaves), which is the primary global marker for identifying the base of the Carnian Stage. The secondary marker for the Carnian Stage, the conodont Paragondolella polygnathiformis (Budurov and Stefanov), appears $70 \mathrm{~cm}$ above the first occurrence of Daxatina canadensis and at the base of a long normal-polarity magnetic zone (S2n) in close proximity to the boundary. Furthermore, the GSSP is located one ammonite subzone just above a level dated at $237.77 \pm 0.14 \mathrm{Ma}$.

\section{Introduction}

This paper is the final description of the Global boundary Stratotype Section and Point (GSSP) for the base of the Carnian Stage after its ratification in the Spring of 2008 by the IUGS Executive Committee, following its approval by the International Commission on Stratigraphy (12 votes Yes [80\%], 3 abstentions, 3 votes not received) and a previous favourable vote by the Subcommission on Triassic Stratigraphy on the modified version of the proposal by Broglio Loriga et al. $(1998,1999)$ and Mietto et al. (2007a) (13 votes Yes [100\%], 5 votes not received). After the GSSPs of the Induan and Ladinian stages (Hongfu et al., 2001; Brack et al., 2005), this is the third ratified GSSP within the Triassic System. Here we briefly review the historical and regional geological context of the Ladinian-Carnian boundary interval and then discuss in detail the criteria for selecting the principal stratigraphic markers, the location of the GSSP and the possibilities for regional and global correlations.

\section{Historical context of the Carnian Stage}

The history of concepts regarding the Ladinian-Carnian boundary is summarized in Krystyn (1978), Gaetani (1995) and Broglio Loriga et al. (1999). As it is well known, the base of the Carnian in the Tethys realm traditionally coincided with the appearance of the ammonoid Trachyceras aon, regarded as the first representative of the genus. The genus Trachyceras is documented at Prati di Stuores/ Stuores Wiesen by the occurrence of Trachyceras muensteri associated with Daxatina canadensis, largely below the appearance of $T$. aon. Also the nearby Bec de Roces section yields an ammonoid association in which the genus Trachyceras, in particular T. muensteri, occurs closely associated with representatives of Daxatina (Mietto et al., 2008: 386). This implies that the genus Trachyceras predates the aon 
Subzone and allows the preceding canadensis Subzone to be considered Carnian in age (Mietto and Manfrin, 1995a, 1995b). This observation is corroborated by conodonts and palynomorphs, as well (see below).

\section{The Carnian GSSP at Prati di Stuores/ Stuores Wiesen section and supple- mentary stratigraphic information}

\section{Geographic location}

The GSSP section at Prati di Stuores/Stuores Wiesen (Province of Belluno, Veneto Region, Italy) is located on the northern flank of the Cordevole Valley, on the southern slopes of the crest separating the Badia/Abtei Valley and the Cordevole Valley in the Dolomites
(Southern Alps) (Fig.1). The Prati di Stuores section (German: Stuores Wiesen) lies some hundred meters east of Pralongià, a locality northeast of Arabba (Cordevole Valley). It extends from a base elevation of $1980 \mathrm{~m}$ to the crest at $2150 \mathrm{~m}$ along a deeply incised gully. The section continues upwards through the overlying meadows and ends at the toe of the vertical walls of the Piccolo Settsass (the well known Richthofen Riff of Mojsisovics, 1879) and of the Settsass.

The section can be easily reached from Rifugio Pralongià following C.A.I. footpath n. 23 towards the Settsass peak, a few hundred meters east-southeast of Piz Stuores $(2181 \mathrm{~m})$. Pralongià is easily attainable by footpaths (C.A.I. n. 22, n. 23, n. 3) and from all the surrounding localities including San Cassiano/St. Kassian, Corvara/Kurfar (Badia/Abtei Valley), the Campolongo Pass, and also following gravel roads from Corvara/Kurfar (intersection at $\mathrm{km} \mathrm{35,}$ S.S. 244) and Renaz (intersection at km 88, S.S. 48) or by chair-lift from Rifugio Cherz near Campolongo Pass.
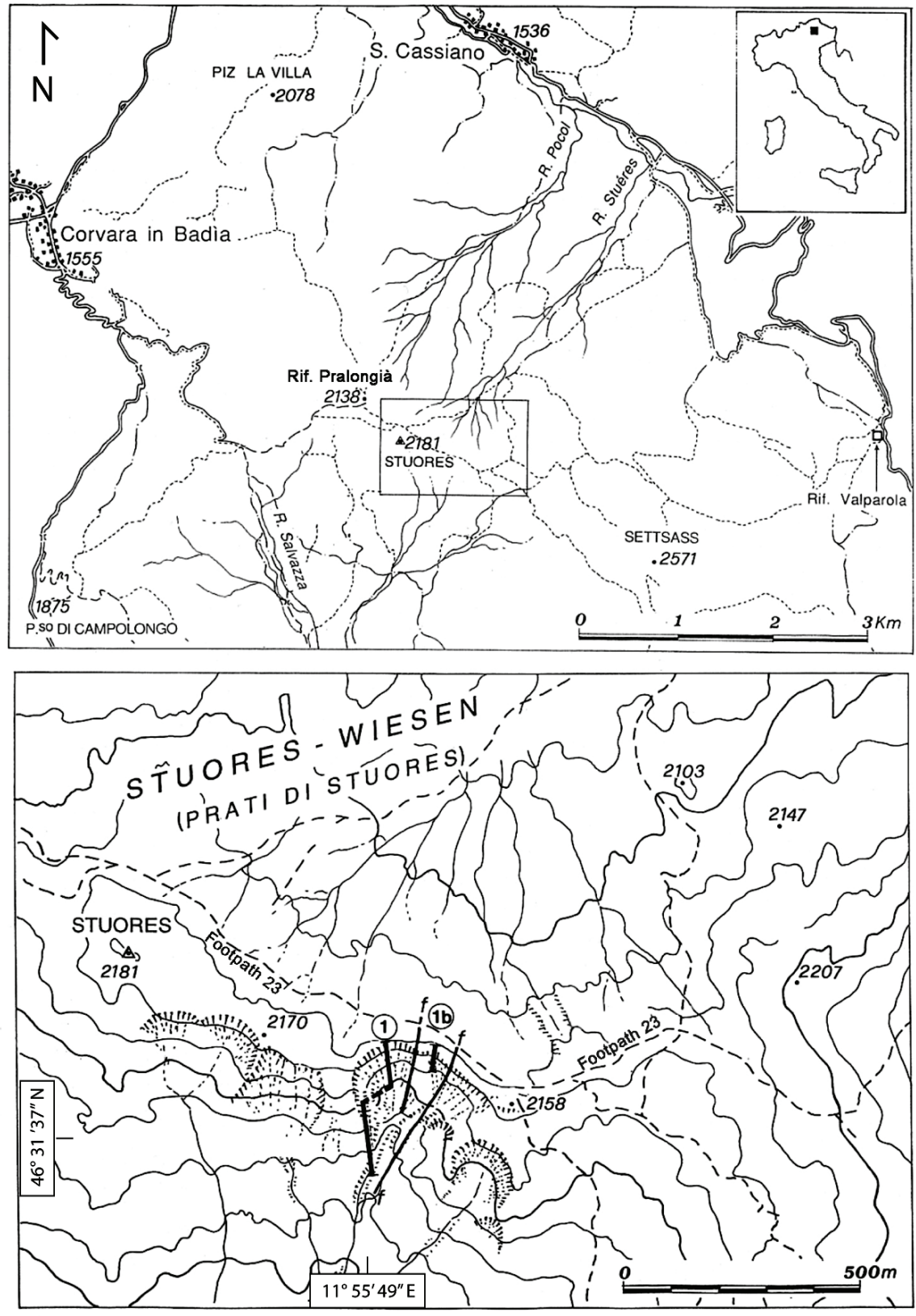

Figure 1. Location map of the Prati di Stuores/Stuores Wiesen section (from Broglio Lorigo et al. 1999; modified).

\section{Geological setting}

The Prati di Stuores/Stuores Wiesen section is located in the Dolomites region, which constitutes the northcentral portion of the Southern Alps (Doglioni, 1987; Castellarin and Cantelli, 2000). The Southern Alps comprise a southvergent thrust belt of the unmetamorphosed passive continental margin sequence of the Mesozoic Tethys. In the Dolomites, the sedimentary succession spans Permian to Oligocene time, but it is considered a global reference for the Triassic System (cf. Bosellini et al., 2003; Gianolla et al., 2009).

The Dolomites stratigraphy records several tectonic and magmatic events including the Late Ladinian emplacement of epicrustal intrusions (Monzoni, Predazzo, Cima Pape) and shoshonitic volcanism (cf. Viel, 1979; Pisa et al., 1980; Sloman, 1989). The latter was a key event in the stratigraphic record of the Dolomites and led to the deposition of both volcaniclastic sedimentary rocks and lava flows under subaerial and submarine conditions (Fernazza Fm.). Tectonic activity related to the volcanism triggered submarine collapse of the pre-volcanic successions, and their deposition as megabreccias interbedded with the coeval volcaniclastics. These units constitute the base of the described succession at Prati di Stuores (Broglio Loriga et al., 1999). The stratigraphic succession records the erosion of volcanic edifices and deposition as thick units of deep-water volcaniclastic conglomerates, arenites and shales (Wengen Fm.), in part facilitated by a relative sea-level fall. The internal organization of the Wengen Fm. indicates progradation of turbiditic lobes towards the basin depocenter and its lithofacies reflects distance from the source area(s). Locally, small carbonate platforms have been documented (mostly with fringing reef geometries) which were the sources of carbonaceous ("Cipit") boulders, as well as 
biocalcarenites (Stefani et al., 2010). A reduction in erosion rate related to sea-level rise and the onset of rimmed carbonate platforms (Cassian Dolomite) led to a reduced siliciclastic input and dominance of carbonates in the basins (San Cassiano Fm.). The above transition from volcaniclastic deposition to shallow carbonate sedimentation can be observed in the area of Prati di Stuores/Stuores Wiesen. The subsequent basin evolution is characterized by a progressive shallowing resulting in a complete closure of the basin during Late Carnian times (Heiligkreuz and Travenanzes Fms.).

\section{Location of section and boundary}

Several outcrops exposing the upper Wengen and the San Cassiano Formations are present at Prati di Stuores/Stuores Wiesen. Most of them expose long sections, which are easily correlated by tracing individual beds. The section exposed at $46^{\circ} 31^{\prime} 37^{\prime \prime} \mathrm{N}, 11^{\circ} 55^{\prime} 49^{\prime \prime} \mathrm{E}$ and with a base elevation of $1980 \mathrm{~m}$ is selected as Standard Section because it exposes the longest continuous succession (Fig. 2).

The GSSP of the base of the Carnian Stage is located at the base of bed SW4, $45 \mathrm{~m}$ above the base of the San Cassiano Fm. in the Prati di Stuores/Stuores Wiesen stratigraphic section (Figs. 3, 4). Bed SW4 is a marly limestone immediately underlying an arenite bed in the lower San Cassiano Fm. The bed yields ammonoids, including Daxatina canadensis (Whiteaves), the primary marker for identifying the boundary.

\section{Stratigraphic completeness}

The Prati di Stuores/Stuores Wiesen section is characterized by a thick interval of marine sediments deposited below storm wave-base. The depositional facies consists of hemipelagites and thin turbidite beds (both siliciclastic and derived from nearby carbonate platforms) indicating high but variable sedimentation rates. In detail, a slight increase in sedimentation rate is expected towards the upper part of the section accordingly to an overall regressive trend. Terrigenous sedimentation decreases upwards in parallel with increased carbonate supply from the prograding carbonate platforms (Cassian Dolomite).

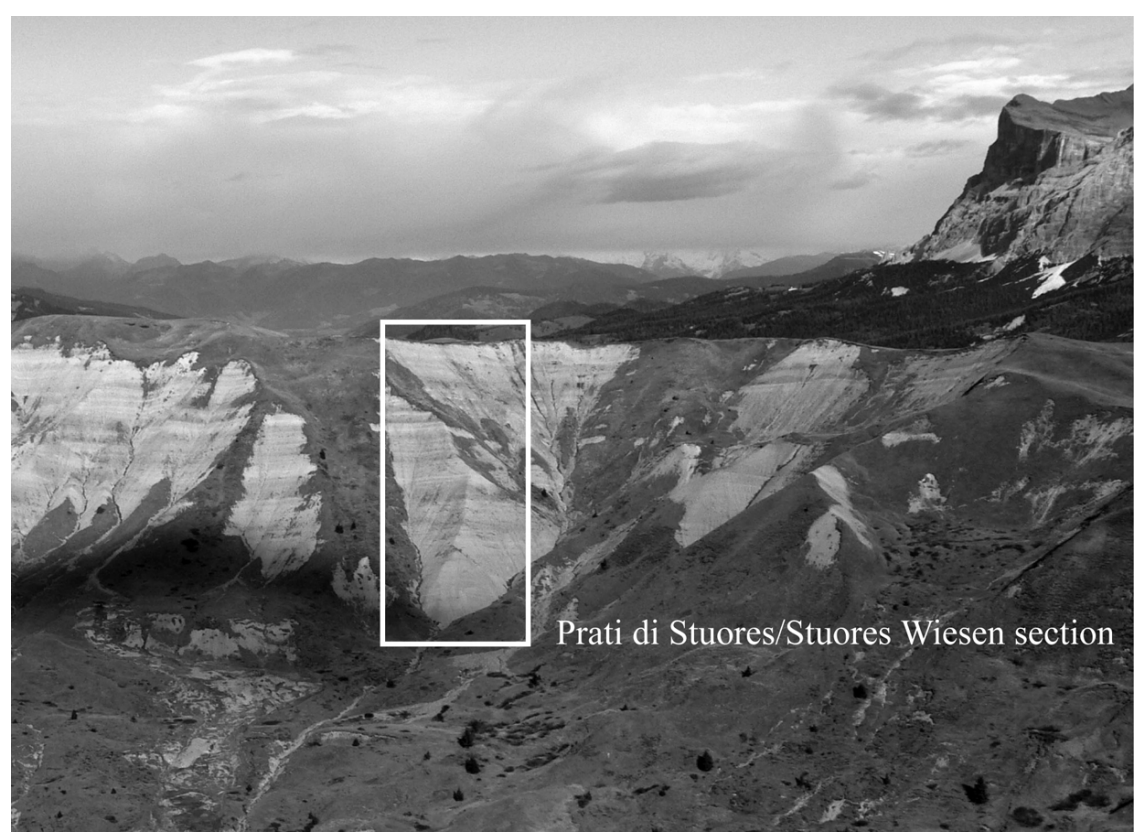

Figure 2. Landscape view of the Prati di Stuores/Stuores Wiesen section.
Slumps and slump scars are recognized in the upper part of the section, but are absent from the GSSP level. Such sedimentary features do not involve considerable thickness and therefore do not correspond to significant stratigraphic gaps. Indurated beds and non-depositional and/or condensed intervals are absent from the studied succession.

\section{Thickness and stratigraphic extent}

The main part of the Prati di Stuores/Stuores Wiesen section, excluding its upper interval referred to as the aon and part of the aonoides subzones (Urlichs, 1974; 1994), encompasses $200 \mathrm{~m}$ of hemipelagic beds of the Wengen and San Cassiano Formations. This succession exceeds $220 \mathrm{~m}$ if the correlated section 1 bis is considered (Fig. 1). Moreover, outcrops are laterally continuous over distances of several hundreds of meters (Fig. 2). Ammonoids are abundant throughout the section.

The uppermost Ladinian regoledanus Subzone immediately below the GSSP boundary is represented by ca. $65 \mathrm{~m}$ of shale, marl and arenites. The first biozone of the Carnian, the canadensis Subzone, is widely represented in the section up to the $194.3 \mathrm{~m}$ level, where the boundary with the overlying aon Subzone is documented in section 1bis. The Prati di Stuores/Stuores Wiesen section hence encompasses all or parts of three ammonoid subzones. This stratigraphic interval is relatively short if compared with the total thickness of the succession; a considerable thickness of stratigraphic succession is allowed below and above the GSSP, in order to extend the stratigraphy and to ensure a robust definition of the GSSP. This is a consequence of high sediment accumulation rates that characterized the Cassian basin between the late Ladinian and the early Carnian.

\section{Provisions for preservation and protection}

The accessibility of the Prati di Stuores/Stuores Wiesen section has been documented since the early $19^{\text {th }}$ century, thanks to the classical works of Münster (1834), Wissmann and Münster (1841), and Klipstein (1845), followed by those of Laube (1869), Mojsisovics (1882), Ogilvie Gordon (1893, 1929), Urlichs (1974, 1994), and others. This historical record highlights the endurance of the natural outcrops. The section area was involved in small but frequent landslides, due to the steep cliff exposure and the lithological nature of the involved units consisting of marls, volcaniclastic arenite and thin bio-calcarenite alternations. The chosen section, however, lies on a steep rise, about $75 \mathrm{~m}$ above the slope base. This high-standing location prevents landslide and debris-flow deposits from accumulating on the section outcrops. The significant lateral continuity of the outcrop also ensures good preservation potential for the GSSP.

The Prati di Stuores/Stuores Wiesen area belongs to the system "Dolomiti Settentrionali/ Nördliche Dolomiten" which is part of the Dolomites natural property included in the UNESCO World Heritage List from 2009 for criteria vii and viii (http://whc.unesco.org/en/list/1237/). The area is also protected by the Code for cultural and landscape assets (Law Decree n. 42, 2004), preserving the whole of the territories above $1600 \mathrm{~m}$, 


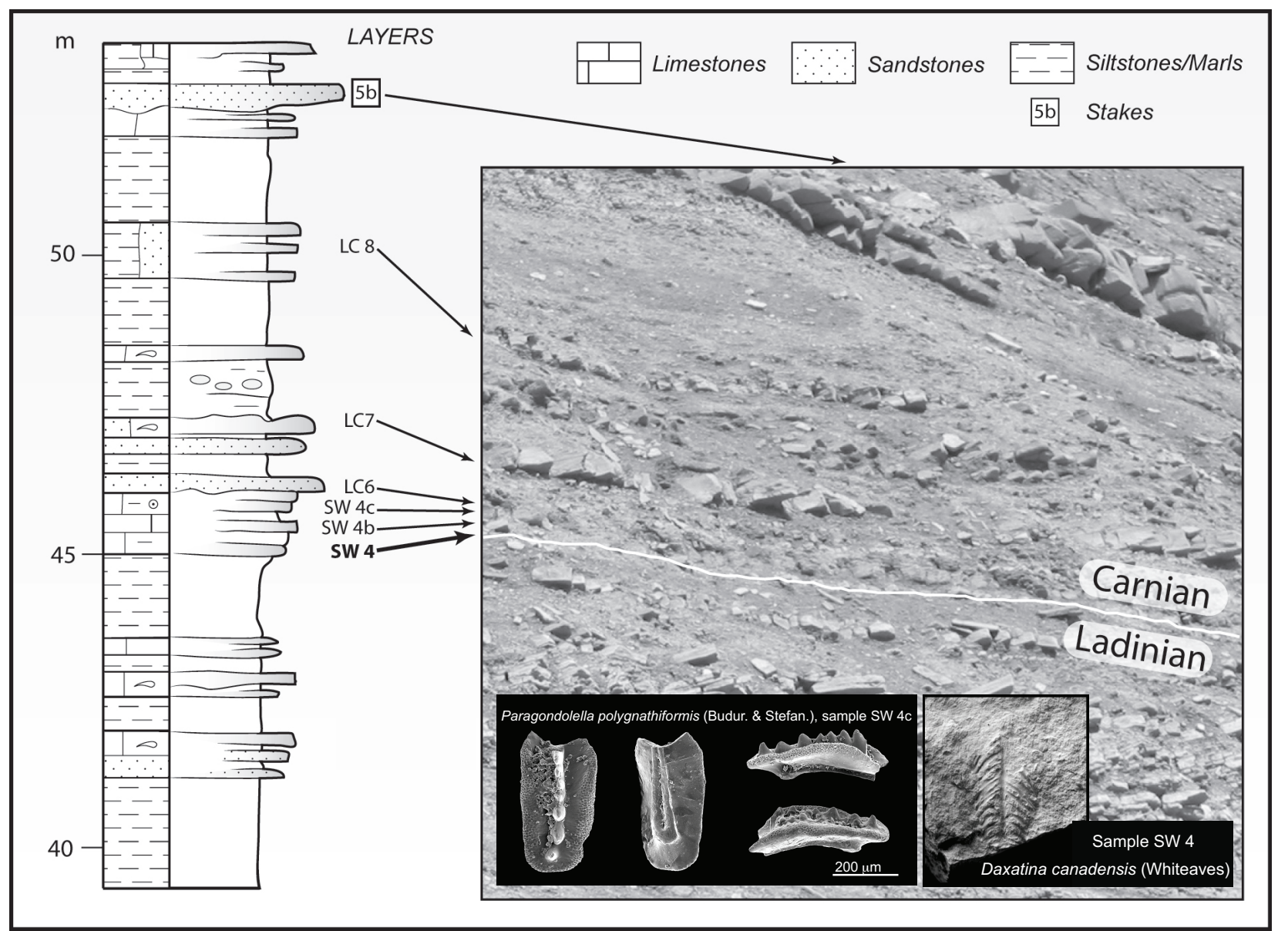

Figure 3. Log and outcrop view of the Prati di Stuores/Stuores Wiesen section showing the Ladinian-Carnian boundary in detail.

and it lies within the Col di Lana - Settsass - Cherz protected area (ZPS IT3230086), associated with the directive Natura 2000 (92/43/ CE, 79/409/CE). The local administrations (Comune di Livinallongo del Col di Lana, Provincia di Belluno and Regione Veneto) intend to maintain and mark access to the section and popularize the site.

\section{Primary and secondary markers}

\section{Principal correlation event (marker) at GSSP level}

The GSSP level at Prati di Stuores/Stuores Wiesen is defined by the first appearance (FAD) of the ammonoid species Daxatina canadensis, which corresponds to the first appearance of the genus Daxatina, as identified in the bed SW4. While D. canadensis is confined to the homonymous Subzone of the Tethys and is found in the equivalent part of the sutherlandi 2 Zone of Canada (Tozer, 1994) and most probably in the desatoyense Zone of Nevada (Balini and Jenks, 2007, Balini et al. 2007), the genus Daxatina (D. limpida Tozer, 1994) could be present also in the desatoyense Zone of Canada (Tozer, 1994), but this datum is too far to be confirmed (Mietto and Manfrin, 1999: 26).

Despite some equivocal attributions proposed in the past (i.e. Urlichs, 1974), the genus Daxatina is well documented in the Southern Alps: Prati di Stuores/Stuores Wiesen, Bec de Roces, Antersass, Rio Cuzze and Pista Nera near Sappada (Mietto and Manfrin, 1995a, 1995b; Broglio Loriga et al., 1998, 1999; Manco et al., 2004; Mietto et al., 2007a, 2007b, 2008). Following the early discoveries in British Columbia (Whiteaves, 1889; Tozer, 1994), the Svalbard Archipelago (Böhm, 1903, 1904) and Alaska (Martin, 1926), more recent occurrences in the Himalayan region (Spiti valley: Balini, Krystyn and Torti, 1998; Krystyn, Balini and Nicora, 2004) and Nevada (New Pass Range: Balini and Jenks, 2007; Balini et al., 2007) testify to the global distribution of Daxatina. For this reason, the GSSP level provides an excellent tool for trans-Panthalassa correlations between low to middle-high paleolatitude domains.

\section{Biostratigraphy}

\section{Ammonoids}

At Prati di Stuores/Stuores Wiesen (Fig. 4), the first occurrence of genus Daxatina is documented in bed SW4, with a strongly ornamented specimen referred to as D. canadensis (Mietto et al., 2008: Pl. 6, Fig. 8). A finely ornamented trachyceratid occurs $16.50 \mathrm{~m}$ above the latter bed. This specimen was previously attributed to Trachyceras bipunctatum (Münster) (Mietto and Manfrin, 1995a, 1995b; Broglio Loriga et al., 1999; Mietto et al., 2007b), but is now attributed to Daxatina cf. laubei Tozer, 1994 (Mietto et al., 2007a, 2008). Further up, representatives of Daxatina (chiefly $D$. canadensis) occur along $145 \mathrm{~m}$ of the Prati di Stuores/Stuores Wiesen section. Above this interval, the first appearance of Trachyceras cf. aon (Münster) is recorded in bed SW24. The interval between the first occurrence of Daxatina canadensis and the first occurrence of T. aon was originally 


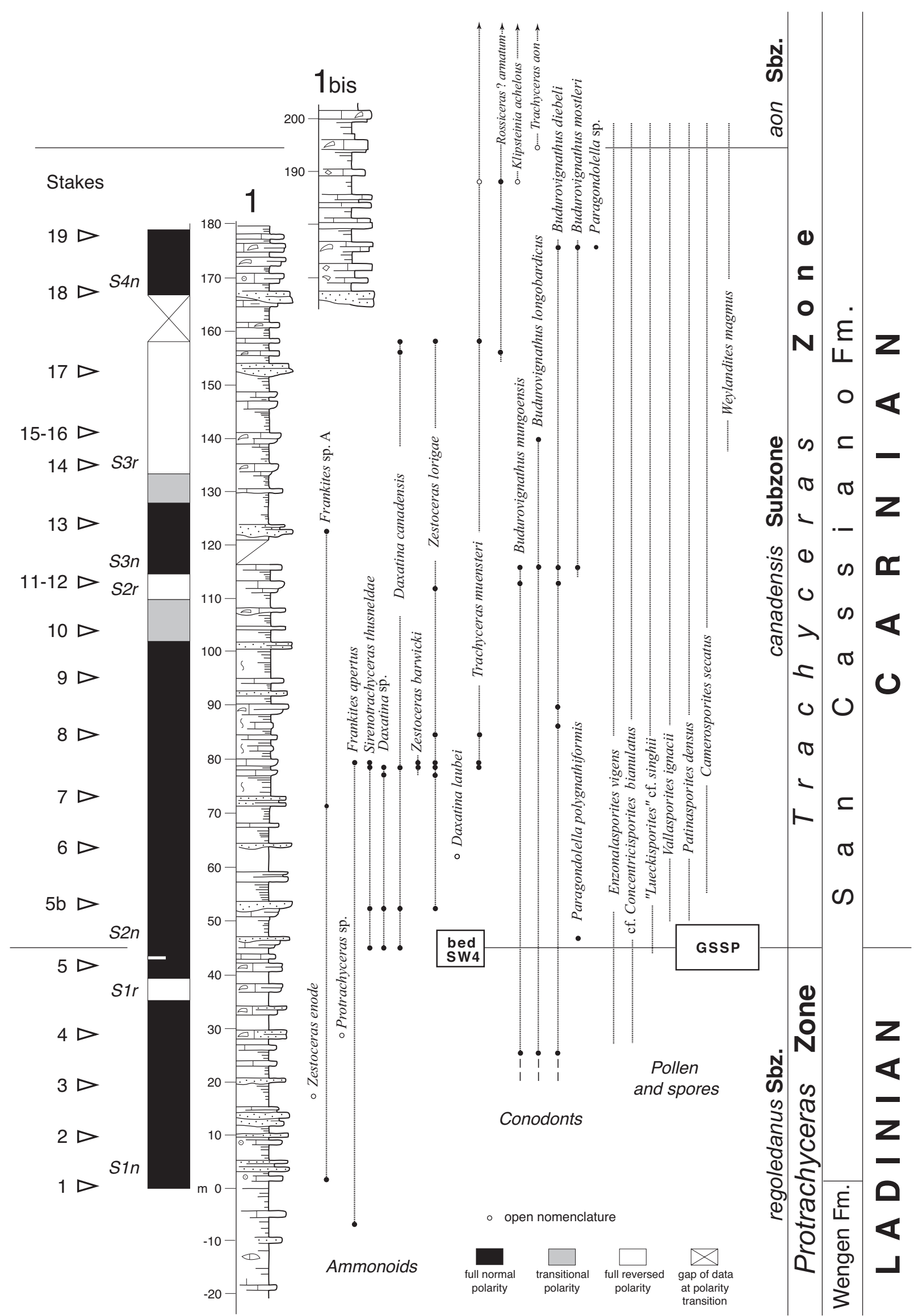

Figure 4. Stratigraphic column of the Prati di Stuores/Stuores Wiesen section with distribution of main fossils, biostratigraphic zonations and magnetostratigraphy (modified from Broglio Lorigo et al. 1999). 
defined as Daxatina cf. canadensis Subzone (Broglio Loriga et al., 1999). The range of the species Daxatina canadensis is limited to the homonymous biozone. Based on subsequent direct comparison with type material from Canada, this unit was formally named canadensis Subzone (Mietto et al., 2007a). It is directly overlain by the aon Subzone, as documented also in the Antersass section (Mietto et al., 2007a, 2007b, 2008). The biozonal interval now referred to as the canadensis Subzone was originally considered equivalent to the sutherlandi Zone (Urlichs, 1974, 1977), then included in the Tethyan regoledanus Zone (Urlichs, 1994), which is documented in the first $65 \mathrm{~m}$ of the Prati di Stuores/Stuores Wiesen section. Less than $34 \mathrm{~m}$ above bed SW4, the first occurrence of Trachyceras is recorded by the species T. muensteri (Wissmann), testifying the appearance of the genus. In particular, this taxon is characterized by a subammonitic suture line, but less indented than, for example, Trachyceras aon. After the attribution of the specimen found in the bed SW6 to Daxatina cf. laubei, the occurrence of Trachyceras bipunctatum in the canadensis Subzone at Prati di Stuores/Stuores Wiesen can no longer be confirmed. Nevertheless, this species has been found in the Antersass section, in the uppermost part of the biozone (Mietto et al., 2007a, 2008).

Two species of genus Frankites are documented at Prati di Stuores/ Stuores Wiesen; the most significant and fairly widespread is Frankites apertus (Mojsisovics). This taxon, which has been considered senior synonymous to Frankites sutherlandi (McLearn) from North America (Mietto et al., 2008), occurs from the upper part of the regoledanus Subzone to at least the lower part of the canadensis Subzone, but probably covers the whole canadensis Subzone. A second species, Frankites sp. A (Mietto et al., 2008, indicated as Frankites johnstoni in Mietto et al., 2007a), occurs sporadically throughout the section.

The best documented genus in the canadensis Subzone is Zestoceras. The first occurrence of Zestoceras lorigae Mietto and Manfrin (Mietto et al., 2008) is in bed SW5b, 7.40 m above SW4. This species is widespread in the canadensis Subzone to which it appears to be confined. A second species, Zestoceras barwicki (Johnston), originally assigned by Johnston (1941) to the genus Clionites, is equivalent to Zestoceras cerastes Tozer. We consider these taxa as synonyms (Mietto et al., 2007a, 2007b, 2008). Moreover, bed SW4 yielded another taxon, Sirenotrachyceras thusneldae (Mojsisovics), which occurs throughout the lower part of the mentioned subzone. The uppermost 10 meters of the biozone (section 1bis), records taxa such as Klipsteinia cf. achelous (Münster) and Rossiceras ? armatum (Münster) that also occur in the aon Subzone. In a bed from a nearby section (SW 11), correlated with the uppermost part of the Prati di Stuores/Stuores Wiesen section, Badiotites eryx (Münster) is recorded.

\section{Conodonts}

Although the Prati di Stuores/Stuores Wiesen section has been investigated several times for conodont biostratigraphy, only a sparse fauna has been observed. This fauna is composed of Budurovignathus mungoensis (Diebel), Budurovignathus mostleri (Kozur), Budurovignathus diebeli (Kozur and Mostler), Budurovignathus longobardicus (Kovàcs) and of the long-ranged species Gladigondolella malayensis malayensis Nogami and Gladigondolella tethydis (Huckriede) (Mastandrea in Broglio Loriga et al., 1999). All of these species range at least from the upper part of the Langobardian (upper Ladinian) to the lower part of the Julian (lower Carnian).
Other correlative sections, Antersass and Bec the Roces, have been studied for both ammonoid and conodont biostratigraphy (Mietto et al., 2007a, 2007b). A similar conodont fauna has been recovered from both sections with the addition of Paragondolella foliata Budurov and the two subspecies Pseudofurnishius murcianus praecursor Gullo and Kozur and Pseudofurnishius murcianus murcianus Van den Boogaard from the Antersass section (Mietto et al., 2007a). Recently, Paragondolella polygnathiformis (Budurov and Stefanov) has been recovered in the Prati di Stuores/Stuores Wiesen section (Manco et al., 2004; Mietto et al., 2007b; Fig. 4, this paper).

Paragondolella polygnathiformis lies on the phylogenetic lineage of Paragondolella inclinata - Paragondolella polygnathiformis Paragondolella noah, a branch of the excelsa-stock which evolved during the late Ladinian - early Carnian (Kovàcs, 1983; Mazza et al., 2011). The species here named Paragondolella polygnathiformis has been ascribed by various authors to different genera such as Neogondolella, Paragondolella or Metapolygnathus. Considering the phyletic evolution as well as the distinguishing characteristics of the above-mentioned genera, as summarized by Kozur (1989), Rigo et al. (2007) and Mazza et al. (2010, 2011), this species is herein interpreted as belonging to the genus Paragondolella. Paragondolella polygnathiformis is characterized by a geniculation point or an abrupt anterior step on both anterior lateral margins. The presence of this feature on only one of the anterior margins is typical of the transitional forms between Paragondolella inclinata (Kovàcs) and Paragondolella polygnathiformis from the latest Ladinian. Paragondolella polygnathiformis differs from the Tuvalian Paragondolella noah (Hayashi) by the absence of a free blade.

Historically, the occurrence of Paragondolella polygnathiformis has been used to define the base of the Carnian (e.g. Krystyn, 1983, Rigo et al., 2007), previously considered to be coincident with the base of the Trachyceras aon Subzone. Nevertheless, as pointed out by Kozur (1980), the range of Paragondolella polygnathiformis extends below the FAD of Trachyceras aon (Kozur 1989; Kovàcs et al., 1991, Gallet et al., 1998) and into the Daxatina canadensis Subzone. At Spiti (India), the first occurrence of Paragondolella polygnathiformis is a few meters below the FO of Daxatina canadensis. At Prati di Stuores/Stuores Wiesen, Paragondolella polygnathiformis has been recovered from sample $S W 4 c, 70 \mathrm{~cm}$ above the first occurrence of Daxatina canadensis in bed SW4. The appearance of Paragondolella polygnathiformis is practically coincident with the FAD of Daxatina canadensis and seems to be an appropriate biohorizon to mark the base of the Carnian Stage. Thus, Pargondolella polygnathiformis ranges from the base of the Julian Substage (basal Carnian), to the lower portion of Tuvalian Substage (upper Carnian) (e.g. Rigo et al., 2007, 2012; Mazza et al., 2012).

\section{Palynomorphs}

The distribution of spores, pollen and organic-walled marine organisms (acritarchs, foraminiferal linings and tasmanitids) in the Prati di Stuores/Stuores Wiesen section reflects the evolution of the terrestrial and marine flora across the Ladinian-Carnian boundary. Thirty four samples have been studied in order to define the distribution of palynomorphs and document their FADs and LADs throughout the succession.

Typical upper Ladinian-lower Carnian sporomorphs including Uvaesporites gadensis, Kuglerina meieri, Ovalipollis pseudoalatus, Todisporites spp., Aratrisporites spp., Reticulatisporites dolomiticus, 
Sellaspora rugoverrucata and the circumpollen form Partitisporites novimundanus are present throughout the section. In the upper part of the regoledanus Subzone, Concentricisporites cf. C. bianulatus, Enzonalasporites vigens, Kyrtomisporis ervii, Gordonispora fossulata and Duplicisporites granulatus have their first occurrence. "Lueckisporites" cf. singhii first appears very close to the top of the regoledanus Subzone. Moreover, Nevesisporites vallatus, Todisporites marginales, Calamospora sp. A, Apiculatisporites parvispinosus and Densosporites cf. variomarginatus are restricted to the regoledanus Subzone. Nevesisporites vallatus has its last occurrence at the GSSP boundary level.

In the lower part of the overlying canadensis Subzone, Vallasporites ignacii, Patinasporites densus and Aulisporites cf. A. astigmosus, together with Duplicisporites verrucosus and Camerosporites secatus, have their first occurrence (Fig. 4). The uppermost part of the canadensis Subzone is characterized by the first occurrences of Weylandites magmus, Camerosporites pseudoverrucatus and Samaropollenites speciosus. No associated bioevents are documented from the overlying aon Subzone.

The palynological content of the Prati di Stuores/Stuores Wiesen section provides useful auxiliary biostratigraphic markers, along with the FAD of Daxatina canadensis, to define the Ladinian-Carnian boundary. The primary ammonoid turnover occurs indeed close to the replacement of upper Ladinian sporomorphs by a typical Carnian microflora.

The first appearance of Patinasporites densus marks the base of the vigens-densus phase in association with the first appearance of Vallasporites ignacii (Van der Eem, 1983); their common occurrence has been traditionally considered to be close to the base of the Carnian (Van der Eem, 1983, Fisher, 1972; Visscher and Brugman, 1981; Fisher and Dunay, 1984; Warrington, 1996; Hochuli and Frank, 2000; Roghi, 2004). Previous palynological work by Van der Eem (1983)placed the Ladinian-Carnian boundary in the Prati di Stuores/Stuores Wiesen section at sample Stu 2-09 AL, corresponding to the base of their vigens-densus phase and to sample 3 of Urlichs (1994) from the same section. Van der Eem's sample Stu 2-09 AL is located above our uppermost sample (sw af, $193.5 \mathrm{~m}$ above base). Therefore, our data suggest that the base of the vigens-densus phase in the Prati di Stuores/Stuores Wiesen section is at least 130 meters lower than that proposed by Van der Eem (1983). In fact, the occurrence of the typical Carnian species Vallasporites ignacii and Patinasporites densus very close to the GSSP boundary and in association with Enzonalasporites vigens extends the range of this palynological association from the lower part of the canadensis Subzone to the vigens-densus phase of Van der Eem (1983). These data support the proposal to place the base of the vigens-densus phase close to the base of the canadensis Subzone (Broglio Loriga et al., 1999).

In the Prati di Stuores/Stuores Wiesen section, the first occurrence of Concentricisporites cf. C. bianulatus within the regoledanus Subzone reveals that the base of the Concentricisporites cf. $C$. bianulatus assemblage is late Ladinian (Longobardian) in age (Roghi, 2004).

\section{Halobiids and other macro- and microfossils}

The lower San Cassiano Fm. was deposited within a deep basin well below the photic zone, with a high sediment accumulation rate and oxygen-deficient bottom conditions (e.g. Fürsich and Wendt,
1977; Broglio Loriga et al., 1999). This environment was hospitable only to posidonioids, an opportunistic bivalve group well adapted to low-oxygen benthic habitats (e.g. Wignall, 1994; Aberham, 1994). For these reasons, bivalves of the lower San Cassiano Fm. of Prati di Stuores/Stuores Wiesen section (uppermost regoledanus and canadensis subzones) are mainly represented by members of the superfamily Posidonioidea (sensu Waller in Waller and Stanley, 2005), while gastropods and brachiopods are rare. Specimens of the latter two groups mostly occur as of the middle canadensis Subzone (Posenato in Broglio Loriga et al., 1999: tab. 6). Posidonioids are common throughout the whole canadensis Subzone, where they generally occur in the laminated, dark-grey clay and argillaceous marls intercalated with turbidites. The posidonioids of the canadensis Subzone are distinguished into three groups (Posenato in Broglio Loriga et al., 1999): a) "Posidonia" wengensis (Wissmann); b) "Posidonia" cf. wengensis; and c) ?Halobia sp. As largely discussed in Mietto et al. (2007b), the lack of posidonioids with an indisputable anterior auricle prevents the unequivocal identification of Halobia in the canadensis Subzone of the Prati di Stuores/Stuores Wiesen section, although the group (c) specimens could contribute to the problem of phyletic connection between Bositra, Daonella and Halobia. Also in the Tethys domain (e.g. the Himalayas) the true Halobia appears only at the base of the Carnian aon Zone (see Balini, Krystyn and Torti, 1998). On the other hand, as demonstrated by Waller and Stanley (2005), McRoberts (1993, 2000) and Balini et al. (2007), the appearance of undoubted Halobia precedes that of the transitional forms documented from the Ladinian sutherlandi Zone of North America.

Data on foraminifers, microcrinoids and holothurian sclerites are reported in Broglio Loriga et al. (1998, 1999). In particular, benthic foraminifers were studied in thin section and in isolated material by C. Broglio Loriga, R. Rettori and D. di Bari (Broglio Loriga et al., 1999). In a previous proposal for the GSSP (Broglio Loriga et al., 1999), these authors recognized the Carnian affinity of the foraminifera along the whole section and suggested that variation in taxonomical compositions may have depended on ecological factors. Microcrinoids and holothurian sclerites were studied by G.F. Laghi and M. Rechichi (Broglio Loriga et al., 1999). The microcrinoid and holothurian sclerites association seems to be rather common to the canadensis Subzone; it also extends upwards into the aon Subzone with only minor changes. In this case, variations in taxonomic diversity can probably be related to ecological factors, as well.

\section{Magnetostratigraphy}

A total of 96 paleomagnetic core samples were analyzed for magnetostratigraphy (Broglio Loriga et al., 1999). A bipolar characteristic component of magnetization oriented in geographic coordinates north and positive or south and negative was isolated in $72 \%$ of the specimens in the temperature range comprised usually between about $200^{\circ} \mathrm{C}$ and $450^{\circ} \mathrm{C}$, up to $550-580^{\circ} \mathrm{C}$. In $10 \%$ of the specimens the characteristic component could be followed up to maximum unblocking temperatures of $600-630^{\circ} \mathrm{C}$. An additional $11 \%$ of the samples show transitional directions associated with polarity excursions or acquired during field polarity reversals. The bipolar and transitional characteristic component directions become shallower upon correction for bedding tilt. Rock-magnetic experiments point to magnetite as the main carrier of the magnetic remanence; subsidiary iron sulphides and hematite are occasionally present. The latitude of the specimen virtual geomagnetic pole (VGP) with respect to the 
overall mean north paleomagnetic pole was used to delineate magnetic polarity stratigraphy. The latitude of the VGPs defines, from bottom to top, a lower normal (S1n)-reverse (S1r)-normal (S2n)-reverse (S2r)normal (S3n)-reverse (S3r)-normal (S4n) polarity sequence. The base of the Carnian, as defined by the FAD of Daxatina canadensis, falls towards the base of S2n (Fig. 4). The Prati di Stuores/Stuores Wiesen section can be tentatively correlated with the coeval Mayerling section from Austria of Gallet et al. (1998). According to this correlation (Broglio Loriga et al., 1999; Hounslow and Muttoni, 2010), the FAD of Daxatina canadensis at Prati di Stuores/Stuores Wiesen would fall at Mayerling within the diebeli conodont Assemblage Zone.

\section{Chemostratigraphy}

The Prati di Stuores/Stuores Wiesen section has been investigated for carbon and oxygen stable isotope variations. One hundred and two samples of fine-grained carbonate were collected from the entire section of Prati di Stuores/Stuores Wiesen (Fig. 5). A small amount of rock (a few grams) from each sample was hand-drilled so as to avoid macrofossils (bivalve shells), intraclasts or fracture-filling calcite. The drilled powder is thus considered representative of the bulk groundmass of the sample. Powders were reacted with phosphoric acid and analyzed using an automated continuous-flow isotope ratio mass spectrometer at the University of Innsbruck. Results were calibrated against NBS and IAEA standards and are reported relative to VPDB scale. The long-term analytical uncertainties are $\pm 0.07 \%$ o for $\delta^{13} \mathrm{C}$, and $\pm 0.08 \%$ or for $\delta^{18} \mathrm{O}$ (reported at the $1 \sigma$ level, Spötl and Vennemann, 2003; Spötl, 2011).

Oxygen isotope values are strongly biased towards low values, being potentially overprinted by diagenesis, but also the $\delta^{13} \mathrm{C}$ values scatter over a wide range of values. In a plot of carbon versus oxygen isotope compositions (inlet in Fig. 5), however, most samples with high carbon and oxygen isotope values form a narrow cluster. It is suggested that this cluster represents nearly pristine $\delta^{13} \mathrm{C}$ values, representative of the contemporary seawater, while other samples depart from this composition because of diagenetic processes. Samples with high carbon and depleted oxygen isotope values may have been altered by water-rock interaction in a nearly closed diagenetic system (Marshall, 1992), while the carbonate of samples with low carbon and high oxygen isotope values may have been partially influenced by bacterial sulfate reduction (Machel, 2001). Samples with high carbon and oxygen isotope values were conservatively taken as those most probably retaining the original seawater $\delta^{13} \mathrm{C}$ signal, and were identified using the method described in Preto et al. (2009). The $\delta^{13} \mathrm{C}$ values of these samples are clearly lower than those expected for the Carnian (Korte et al., 2005, Veizer et al., 1999, Richoz et al., 2007) and also do not change throughout the section, except for some oscillations in the order of less than $0.5 \%$ o. A similar trend was documented from the correlated section of Weissenbach in Austria (Richoz et al., 2007). Although the small wiggles of the $\delta^{13} \mathrm{C}$ curve seem to correlate between the two records, these oscillations approach the limit of precision of the method and need to be validated by further studies before the carbon isotope data can be used as a correlation tool near the Ladinian-Carnian boundary.

\section{Sequence Stratigraphy}

In the last thirty years, the Dolomites have been the subject of extensive sequence stratigraphic analyses; the seismic-scale outcrops, the robust bio-chronostratigraphic framework and the scarce alpine deformation rendered this region an ideal reference for the Triassic Tethys (cf. Brandner, 1984; De Zanche et al., 1993; Rüffer and Zühlke, 1995; Neri and Stefani, 1998; Gianolla et al., 1998; Stefani et al., 2010). The sequence stratigraphic framework was enhanced through basinal-platform correlations, a careful investigation at the scale of the entire western Tethys (Southern Alps, Northern Calcareous Alps and Transdanubian Range), and through refined radioisotopic dating. Recently a major revision of the sequence stratigraphic approach has been put forward by Catuneanu et al. (2009). This approach has been applied also to the Triassic depositional sequences of the Dolomites.

Two depostional sequences separated by a sequence boundary have been recognized associated with the upper Ladinian and lower Carnian (Fig. 6). In this work we suggest a slightly younger age of the sequence boundary (correlative conformity sensu Posamentier et al., 1988) compared to that of Broglio Loriga et al. (1999), based on more detailed biostratigraphic data from the Southern Alps. The base of the Car 1 depositional sequence (sensu Gianolla et al., 1998, alternatively named Lad 3 in Hardenbol et al., 1998) is thus placed in the lower regoledanus Subzone, whereas it was previously included in the neumayri Subzone. In the study area the basinal sequence stratigraphy is typically organized as shown in Fig. 6; the sequence boundary is placed at the sharp, and locally erosional, contact between coarse conglomerates (Marmolada $\mathrm{Cgm}$ /Wengen Fm.) and the underlying volcanics, volcaniclastics and locally marly limestones (Fig. 10) of the Fernazza Fm. (previous HST deposits). The lower part of the Wengen Fm. is characterized by conglomerates, mass flow and channelized high-density turbidites representative of the falling stage system tract (FSST). Above the conglomerates and massive sandstones, thin bedded low-density turbidites interbedded with dark pelites, volcaniclastic sandstones and conglomerates represent the lowstand prograding complex (LST). In the volcaniclastic succession there are intervals characterized by chaotic swarms of carbonate olistoliths and horizons of channelized carbonate breccias that reflect either the erosion of syn- to post-volcanic carbonate platforms or the progradation of coeval platforms. Above the carbonate olistoliths, a decrease in the siliciclastic supply was accompanied by the deposition of volcaniclastic sandstones, pelites, marls and thin beds of grey or reddish nodular limestone (TST). The maximum flooding surface (mfs) is marked by a mudstone dominated interval with nodular limestone, placed in the upper regoledanus Subzone. The upper part of the succession is characterized by a general coarsening-up trend with an increase in the siliciclastic and carbonate supply related to the progradation of the terrigenous and carbonate shelf, comprising the highstand system tract (HST). In the Prati di Stuores/Stuores Wiesen section, the GSSP boundary is placed at the beginning of the regressive trend (HST), a few tens of meters above the mud-dominated interval with nodular limestone in which the $\mathrm{mfs}$ is placed. According to Catuneanu et al. (2009) the maximum flooding surface (mfs) is one of the best traceable surfaces for basin-wide correlation. With the very high sediment accumulations rate of Prati di Stuores/Stuores Wiesen, this surface is separated from the GSSP by a few meters, it provides an additional tool for correlation. In sections with lower sedimentation rate, the mfs may be close to or coinciding with the GSSP.

\section{Marine to land correlation potential}

Palynological assemblages provide a valuable tool for 


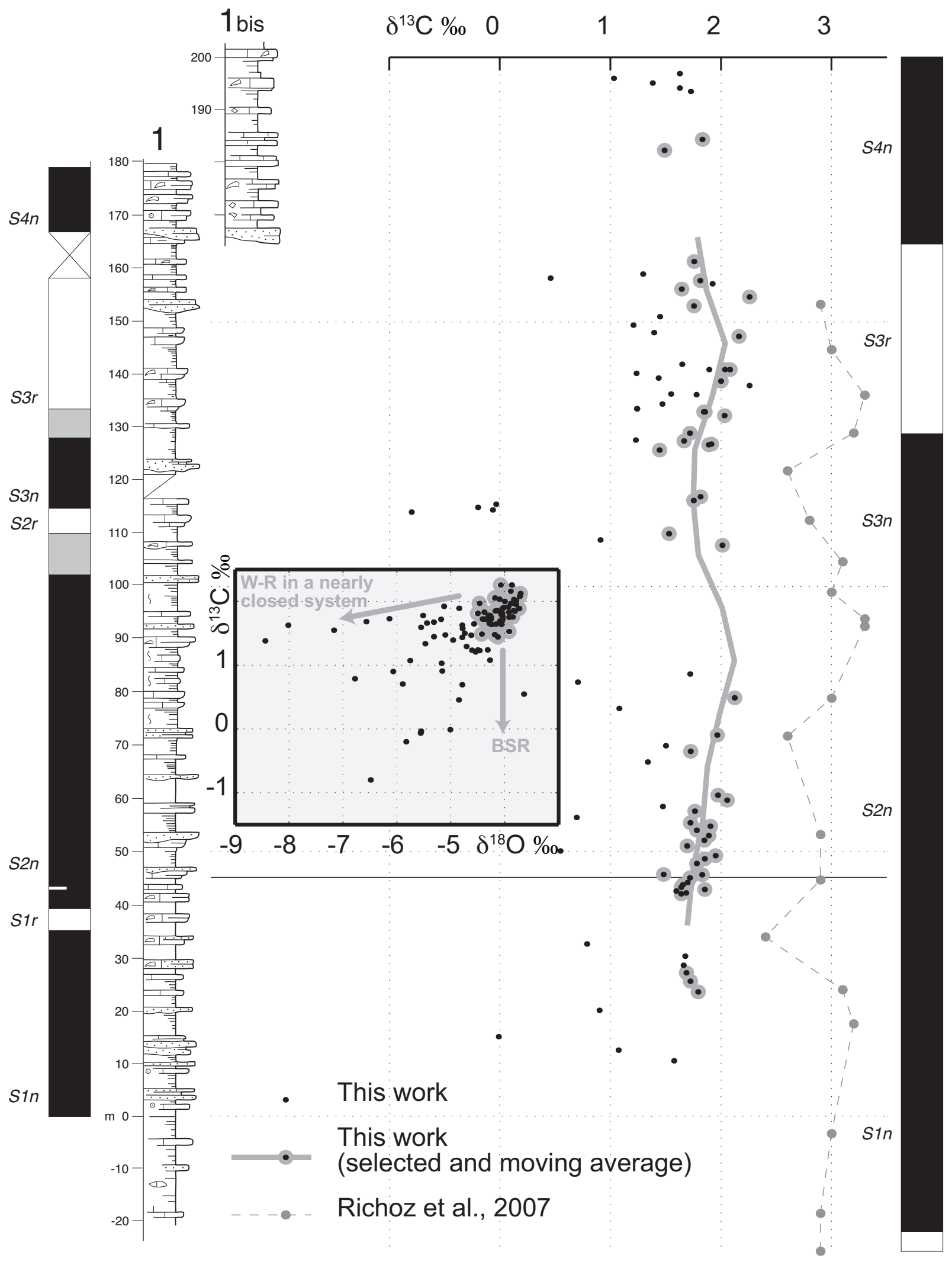

Figure 5. Carbon isotope stratigraphy of the Prati di Stuores/Stuores Wiesen section. Inlet: C-O isotope plot of all samples, with indication of possible diagenetic processes $-W-R=$ water-rock interaction; $B S R=$ bacterial sulfate reduction. Cluster in the upper right corner signifies samples that more likely preserve an original seawater $\delta^{13} \mathrm{C}$ signature, and were identified using the method of Preto et al. (2009). The $\delta^{13} \mathrm{C}$ curve in the main plot is a moving average of selected data with a $10 \mathrm{~m}$ Gaussian window. Data from the Weissenbach section (Richoz et al., 2007) are plotted on the right side for comparison, together with magnetostratigraphic data. The two sections are correlated as proposed by Richoz et al. (2007), based on biostratigraphy and magnetostratigraphy. 


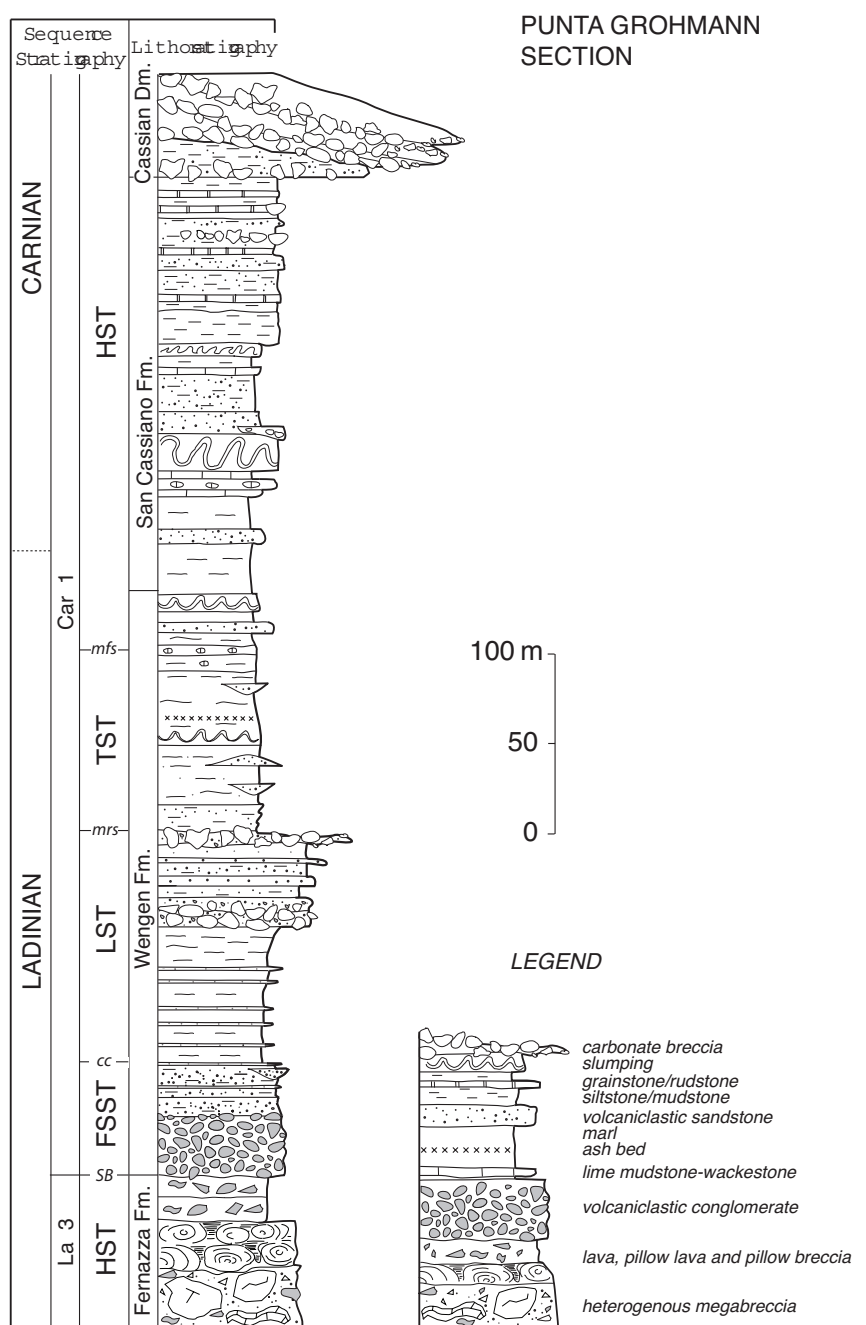

Figure 6. Lithostratigraphy and sequence stratigraphic interpretation of Punta Grohmann section, Val Badia (modified from Russo et al., 1997 and Gianolla et al., 1998). Abbreviations: FSST - falling-stage systems tract; LST - lowstand systems tract; TST - transgressive systems tract; HST — highstand systems tract; $S B=$ Sequence Boundary (correlative conformity sensu Posamentier and Allen, 1999); cc - correlative conformity sensu Hunt and Tucker (1992); mrs = maximun regression surface; $m f s$ = maximun flooding surface.

interregional correlations between marine and continental realms. Spores and pollen are produced on landmasses and widely distributed over both terrestrial and marine environments, from proximal to distal areas. Currently few marine successions in the world provide an ammonoid- and conodont-integrated palynostratigraphy. Therefore the palynological content of Prati di Stores/Stores Wiesen section represents a significant record for marine to land correlation. In Switzerland, Vallasporites ignacii and Patinasporites densus appear in the upper part of the middle Gipskeuper (interval F of Scheuring, 1970 and Mostler and Scheuring, 1974). In southern Germany (Franken), Vallasporites ignacii appears always in the upper part of the Gipskeuper (upper "Myophorienschichten") both in outcrop and in the Obernsees borehole, while Patinasporites densus occurs in the overlying "Estherienschichten". On the basis of these first appearances, the GSSP level can be correlated to the upper part of the Myophorienschichten (Van den Berg, 1987, Brack et al., 1999 and discussion herein). In England, Patinasporites densus was found in the Arden Sandstone and the occurrences of Camerosporites secatus and Enzonalasporites vigens are not isochronous within the "Keuper marl" (Warrington, 1970). So it is not possible to define the precise correlation of the GSSP within the England Keuper. In the Temple Mountain Member of the Chinle Formation (southwestern U.S.A), typical Carnian associations are described from the base of the succession, but the Ladinian/Carnian boundary is not identifiable (Litwin et al., 1991; Litwin and Ash, 1993). In the Newark Supergroup (eastern U.S.A), Vallasporites ignacii and Patinasporites densus have been reported from the uppermost part of the Stockton Formation and lowermost Lockatong Formation (Fowell et al., 1994). Recent magnetostratigraphic studies, however, question this correlation and suggest that the GSSP level lies in the lowermost part of the Newark Supergroup (e.g. Muttoni et al., 2004).

\section{Prospects for High-precision Geochronology}

Calibration of the Late Triassic timescale, in general, is hindered by the paucity of reliable geochronologic data (e.g., Mundil et al., 2010). Multiple volcanic ash beds suitable for radioisotopic dating have been identified in correlatable sections in the vicinity of the Stuores Wiesen GSSP. These include the Alpe di Siusi/Seiser Alm area and the Punta Grohmann sections, $24 \mathrm{~km}$ and $17 \mathrm{~km}$ west of the Prati di Stuores/Stuores Wiesen, respectively.

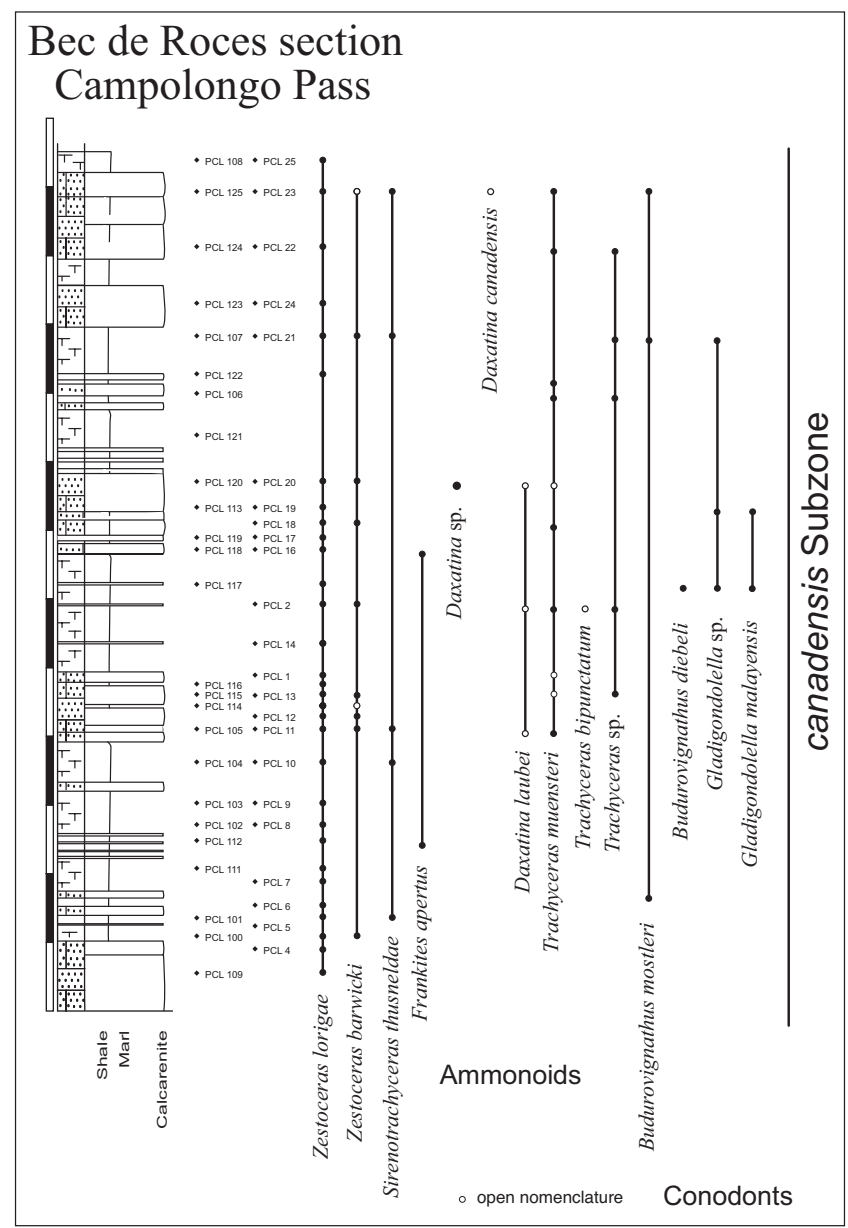

Figure 7. Stratigraphic column of the Bec de Roces section, with distribution of main fossils (modified from Mietto et al., 2008). 


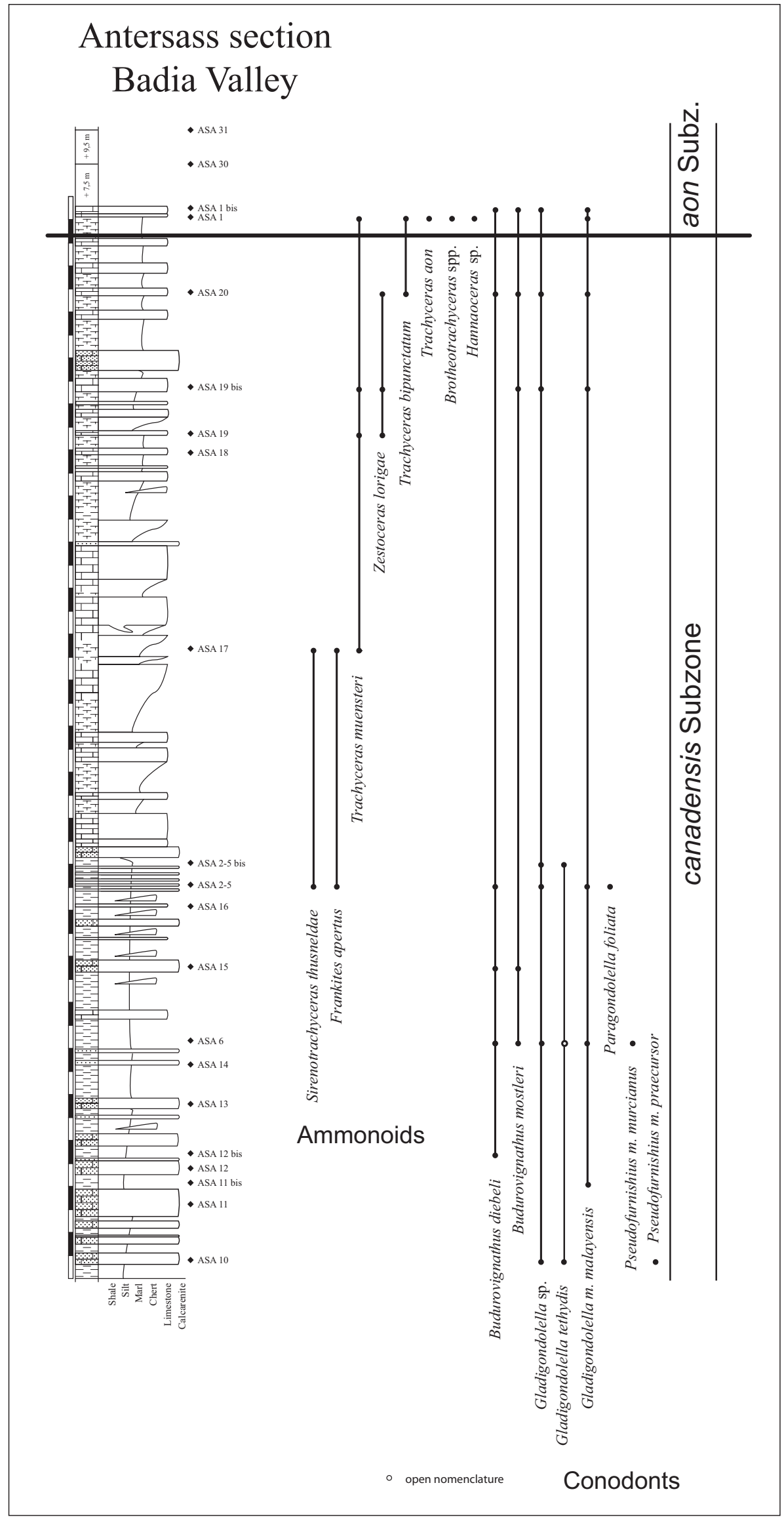

Figure 8. Stratigraphic column of the Antersass section, with distribution of main fossils (modified from Mietto et al., 2008).
Here we present new $\mathrm{U}-\mathrm{Pb}$ zircon geochronology for an ash bed from the Alpe di Siusi/Seiser Alm area that is constrained biostratigraphically close to the neumayril regoledanus subzones (Upper Ladinian; see Figs. 1 and 9). Seven single zircon grains pretreated by the chemical abrasion technique (CA-TIMS of Mattinson, 2005) yielded a weighted mean ${ }^{206} \mathrm{~Pb} /{ }^{238} \mathrm{U}$ date of $237.773 \pm$ $0.052 \mathrm{Ma}( \pm 0.14 \mathrm{Ma}$ taking into account $\mathrm{U}-\mathrm{Pb}$ tracer calibration errors) with an MSWD of 1.6 (Fig. 10 and Table 1). The new Alpe di Siusi/Seiser Alm date is in agreement with a previously reported CA-TIMS date of 239.3 $\pm 0.2 \mathrm{Ma}$ from the gredleri/archelaus zones (Brühwiler et al., 2007). The presence of Protrachyceras steinmanni (Mojsisovics) at a similar stratigraphic level in the correlative Bagolino section (Brack and Rieber, 1993) suggests that this latter age falls into the longobardicum Subzone (sensu Mietto and Manfrin, 1995a), as well. The Alpe di Siusi/Seiser Alm is also in agreement with mechanically abraded (thus more susceptible to $\mathrm{Pb}$ loss) zircon dates of $237.3+0.4 /-1.0 \mathrm{Ma}$ for the Late Ladinian granites at Predazzo (Mundil et al., 1996; Brack et al., 1996, 1997, 2005) and of $238.0+0.4-0.7 \mathrm{Ma}$ from the Seceda section (Mundil et al., 1996) that is close to the longobardicum/neumayri subzones boundary based on the occurrence of Daonella lommeli.

The Carnian geochronology is far from robust, as high-precision age constraints are limited to a CA-TIMS zircon date of $230.91 \pm$ $0.33 \mathrm{Ma}$ for an Upper Carnian ash bed from the southern Apennines (Furin et al., 2006), over $700 \mathrm{~km}$ to the southeast of the GSSP. Biostratigraphic controls based on conodonts and palynomorphs place the dated bed $\sim 6 \mathrm{~m}$ below the Carnian-Norian boundary. According to Kozur and Weems (2007), the ash bed belongs to the Carnepigondolella zoae conodont zone of middle to late Tuvalian (latest Carnian) age. The Carnian age from the southern Apennines is consistent with the Newark Basin astronomically-tuned magnetostratigraphy (Muttoni et al., 2004) and with an ${ }^{40} \mathrm{Ar} /{ }^{39} \mathrm{Ar}$ date of $227.8 \pm 0.3 \mathrm{Ma}$ from the lower part of the terrestrial, tetrapod-bearing, Ischigualasto Formation in Argentina (Rogers et al., 1993). The latter date is recalculated to $230.8 \pm 0.3 \mathrm{Ma}$, taking into account the modern $\mathrm{K}$ decay constant and revised age of the fluence monitor $( \pm 4.5 \mathrm{Ma}$ if the uncertainties of the latter are taken into account; see Ramezani et al., 2011). In the absence of radioisotopic dates from the lower Carnian, the age of the Ladinian-Carnian boundary can only be 


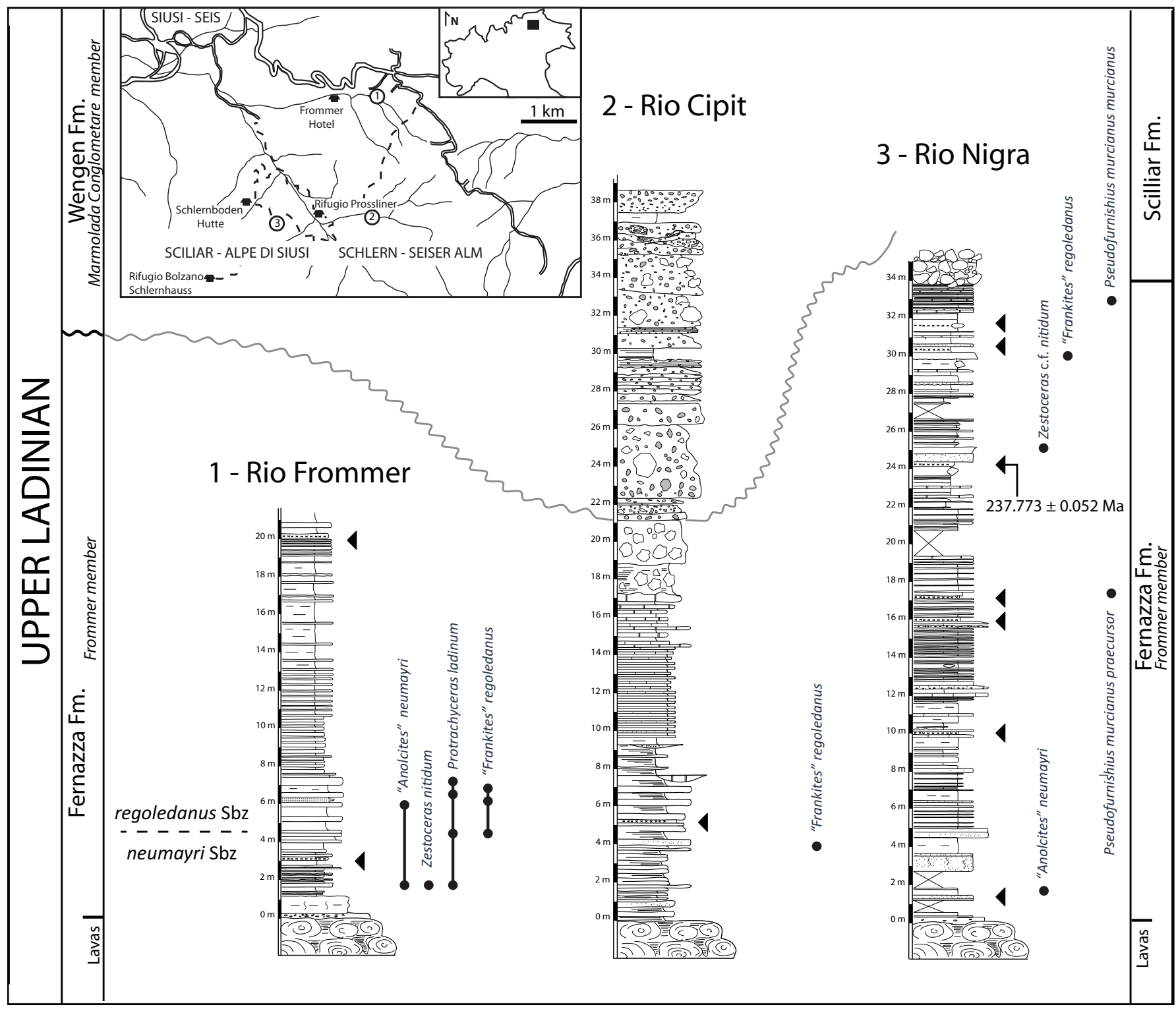

Figure 9. Litho- and bio-stratigraphic correlations in the Alpe di Siusi/Seiser Alm area. Legend as in Fig. 6.

determined by extrapolation. Based on the available geochronologic data combined with the approximate sediment accumulation rates from the Dolomites successions, the age for the Ladinian-Carnian boundary is currently estimated to be close to $237 \mathrm{Ma}$ (see also Gallet et al., 2003; Kozur and Weems, 2007; Mundil et al., 2010).

\section{Demonstration of Regional and Global Correlation}

\section{Regional correlation}

The litho-, sequence-, magneto- and bio-stratigraphic correlations of Ladinian-Carnian boundary interval within the Southern Alps is widely illustrated and discussed in De Zanche et al. (1993), De Zanche and Gianolla (1995), Mietto and Manfrin (1995b), Broglio Loriga et al. (1998, 1999) and Mietto et al. (2008). From a biostratigraphic point of view, several stratigraphic sections and localities in the Southern Alps contain ammonoid faunal assemblages referred to as the canadensis Subzone. Bed by bed distributions of ammonoids, conodonts and palynomorphs in selected key sections are shown in Mietto et al. (2007a, 2007b, 2008). The Bec de Roces section is located on the southeastern flank of the Sella Massif, near Passo Campolongo less than $7 \mathrm{~km}$ from Stuores (Fig. 7). It is a short section that best illustrates the ammonoid association typical of the canadensis Subzone. The Antersass section is located on the northeastern flank of Gardenaccia in the middle Badia Valley. This section is noteworthy for the abundance of fairly well preserved ammonoids that record the boundary between the canadensis and aon subzones (Fig. 8). As demonstrated by Mietto et al. (2008), in this section specimens of Daxatina were found only in the debris fall. However, the ammonoid association, in particular that of Sirenotrachyceras thusneldae, Frankites apertus and Zestoceras lorigae in coexistence with Trachyceras muensteri and T. bipunctatum, is indicative of the canadensis Subzone.

In the course of preparation of this manuscript, outcrops of the the Bec de Roces section were severely damaged due to the construction of a ski-piste and are no longer accessible. 
Table 1. U-Pb data for analyzed zircon from the Upper Ladinian Alpe di Siusi/Seiser Alm ash bed, northern Italy.

\begin{tabular}{|c|c|c|c|c|c|c|c|c|c|c|c|c|c|c|c|c|}
\hline \multirow[b]{2}{*}{$\begin{array}{c}\text { Sample } \\
\text { Fractions }^{\dagger}\end{array}$} & \multicolumn{5}{|c|}{ Composition } & \multicolumn{6}{|c|}{ Ratios } & \multicolumn{4}{|c|}{ Age (Ma) } & \multirow[b]{2}{*}{$\begin{array}{l}\text { corr. } \\
\text { coef. }\end{array}$} \\
\hline & $\frac{\mathrm{Pb}_{\mathrm{c}}^{\ddagger}}{(\mathrm{pg})}$ & $\frac{\mathrm{Pb}^{* \dagger}}{\mathrm{Pb}_{\mathrm{c}}}$ & $\frac{\mathrm{Th}}{\mathrm{U}}$ & $\frac{{ }^{206} \mathrm{~Pb}^{\S}}{{ }^{204} \mathrm{~Pb}}$ & $\frac{{ }^{208} \mathrm{~Pb}^{\#}}{{ }^{206} \mathrm{~Pb}}$ & $\frac{{ }^{206} \mathrm{~Pb}^{\dagger \dagger}}{{ }^{238} \mathrm{U}}$ & $\begin{array}{r}\text { err } \\
(2 \sigma \%) \\
\end{array}$ & $\frac{{ }^{207} \mathrm{~Pb}^{\dagger \dagger}}{{ }^{235} \mathrm{U}}$ & $\begin{array}{r}\text { err } \\
(2 \sigma \%) \\
\end{array}$ & $\frac{{ }^{207} \mathrm{~Pb}}{{ }^{206} \mathrm{~Pb}}$ & $\begin{array}{r}\text { err } \\
(2 \sigma \%) \\
\end{array}$ & $\frac{{ }^{206} \mathrm{~Pb}}{{ }^{238} \mathrm{U}}$ & $\begin{array}{r}\text { err } \\
(2 \sigma) \\
\end{array}$ & $\frac{{ }^{207} \mathrm{~Pb}}{{ }^{235} \mathrm{U}}$ & $\frac{{ }^{207} \mathrm{~Pb}}{{ }^{206} \mathrm{~Pb}}$ & \\
\hline $\mathbf{z 1}$ & 0.4 & 146.7 & 0.78 & 8245.2 & 0.246 & 37589 & $(.06)$ & 26374 & (.25) & 0.05091 & $(.2$ & 237.87 & 0.14 & 237.68 & 235.8 & 0.52 \\
\hline $\mathrm{z} 2$ & 0.4 & 123.1 & 1.00 & 6555.3 & 0.317 & 0.037586 & $(.06)$ & 0.26409 & (.16) & 0.05098 & (.14) & 237.85 & 0.13 & 237.95 & 239.0 & 0.56 \\
\hline $\mathrm{z} 3$ & 0.4 & 1365 & 1.12 & 70666 & 0.354 & 037432 & (.06) & 0.26279 & (.10) & 0.05094 & $(.05)$ & 236.90 & 0.13 & 236.91 & 237.0 & 0.87 \\
\hline $\mathrm{z} 4$ & 0.3 & 287.0 & 0.38 & 17851 & 0.119 & 0.044462 & $(.05)$ & 0.31786 & (.13) & 0.05187 & $(.09)$ & 280.43 & 0.14 & 280.25 & 278.8 & 0.68 \\
\hline $\mathbf{z 5}$ & 0.5 & 172.1 & 1.17 & 8817.1 & 0.370 & 0.037547 & (.06) & 0.26360 & (.17) & 0.05094 & $(.14)$ & 237.61 & 0.14 & 237.57 & 237.1 & 0.62 \\
\hline $\mathrm{z6}$ & 1.0 & 112.4 & 1.19 & 5736.1 & 0.377 & .037576 & $(.06)$ & 0.26417 & (.15) & 0.05101 & $(.12)$ & 237.79 & 0.13 & 238.02 & 240.4 & 0.61 \\
\hline $\mathrm{z7}$ & 1.7 & 65.8 & 1.29 & 3292.5 & 0.408 & 0.037568 & $(.05)$ & 0.26447 & $(.21)$ & 0.05108 & (.18) & 237.74 & 0.13 & 238.27 & 243.5 & 0.58 \\
\hline z8 & 1.5 & 16.3 & 0.74 & 938.8 & 0.234 & 0.037573 & $(.08)$ & 0.26465 & (.68) & 0.05111 & (.63) & 237.77 & 0.19 & 238.41 & 244.7 & 0.62 \\
\hline z9 & 1.7 & 44.7 & 1.50 & 2141.9 & 0.476 & 0.037574 & $(.06)$ & 0.26455 & (.34) & 0.05109 & (.31) & 237.78 & 0.14 & 238.32 & 243.7 & 0.65 \\
\hline
\end{tabular}

Notes: Corr. coef. $=$ correlation coefficient. Analytical procedures are same as in Ramezani et al. (2011). Age calculations are based on the decay constants of Jaffey et al. (1971).

${ }^{\dagger}$ All analyses are single zircon grains and pre-treated by the thermal annealing and acid leaching (CA-TIMS) technique. Data used in age calculations are in bold.

${ }^{*} \mathrm{~Pb}$ c is total common $\mathrm{Pb}$ in analysis. $\mathrm{Pb} *$ is radiogenic $\mathrm{Pb}$ concentration.

$\S$ Measured ratio corrected for spike and fractionation only.

\# Radiogenic $\mathrm{Pb}$ ratio.

${ }^{\dagger}$ Corrected for fractionation, spike, blank, and initial Th/U disequilibrium in magma. Mass fractionation correction of $0.25 \% / \mathrm{amu} \pm 0.04 \% / \mathrm{amu}$ (atomic mass unit) was applied to single-collector Daly analyses. All common Pb is assumed to be blank. Total procedural blank was less than 0.1pg for U. Blank isotopic composition: ${ }^{206} \mathrm{~Pb} /{ }^{204} \mathrm{~Pb}=18.41 \pm 0.48,{ }^{207} \mathrm{~Pb} /{ }^{204} \mathrm{~Pb}=15.41 \pm 0.29,{ }^{208} \mathrm{~Pb} /{ }^{204} \mathrm{~Pb}=37.61 \pm 1.1$.

\section{Long distance and global correlation}

The succession of ammonoid and conodont faunas in the Prati di Stuores/Stuores Wiesen and other correlated sections and sites in the Southern Alps record a number of bioevents that occur homotaxially with those elsewhere in the Tethys as well as the extraTethyan domains (e.g., Himalayas, Nevada, British Columbia, Svalbard) (Fig. 11). In reference to Mietto and Manfrin (1995b) and Broglio Loriga et al. (1999), the occurrence of taxa with widespread

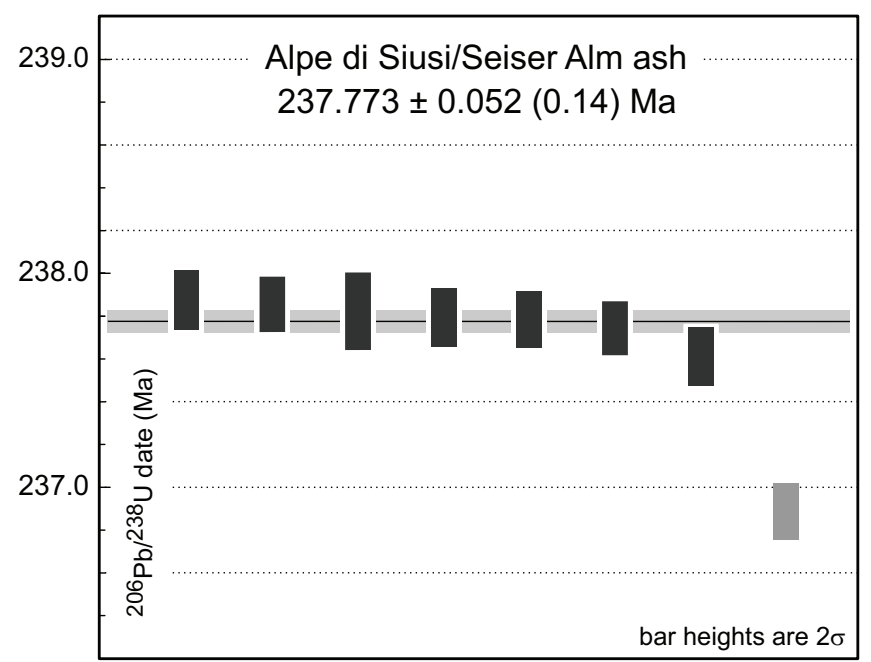

Figure 10. U-Pb date distribution plot for the analyzed zircon from the Alpe di Siusi/Seiser Alm area ash bed. One inherited analysis of older date (z4, not shown here) and one younger outlier ( $z 3$, shaded bar) with indications of residual $\mathrm{Pb}$ loss were excluded from age calculation. Uncertainty in parentheses includes the $U$-Pb tracer calibration errors and is necessary in comparing dates from different $\mathrm{U}$-Pb laboratories. geographic distribution allows the Tethyan biozones to be correlated with those defined in British Columbia by Tozer $(1967,1994)$. In particular, the canadensis Subzone has been considered nearly equivalent to the Canadian sutherlandi Subzone 2 based on the joint occurrence of Daxatina canadensis and Frankites apertus $(=F$. sutherlandi), and correlatable by the first appearance of the former taxon. Nevertheless, the uppermost Ladinian to lowermost Carnian part of the ammonoid-based North American Standard Scale needs to be revised because of the partial overlapping of the sutherlandi and desatoyense Zones, as demonstrated in Nevada (Balini, 2008).

The co-existence of Daxatina, Trachyceras and Frankites apertus $(=$ F. sutherlandi) in the desatoyense Zone of Nevada (Site B of South Canyon in Balini et al., 2007 and Balini and Jenks, 2007) permits a precise correlation with the Prati di Stuores/Stuores Wiesen section. Another important ammonoid species for worldwide correlation is Zestoceras barwicki, documented in Nevada (Johnston, 1941; Jenks et al., 2007), British Columbia (as Zestoceras cerastes by Tozer, 1994), the Bukowina (as Trachyceras armatum in Mojsisovics, 1882, as stated by Mietto et al., 2007b, 2008) and at the Prati di Stuores/Stuores Wiesen section (Mietto et al., 2007b, 2008).

The "Daxatina canadensis Zone", as defined in the Svalbard Archipelago (Bjørnøya, see Mørk et al., 1992) is evidently correlated with the canadensis Subzone. Magnetostratigraphic correlation based on ammonoid vs. conodont calibration between Prati di Stuores/Stuores Wiesen and Mayerling in the Northern Calcareous Alps is shown in Broglio Loriga et al. (1999), and is now confirmed by the discovery of Paragondolella polygnathiformis in bed SW4c, $70 \mathrm{~cm}$ above bed SW4 where Daxatina canadensis first occurs (Mietto et al., 2007b). Also the ammonoid succession recently reported from the canadensis Subzone of the Himalayas (Guling 1 and Muth 3 sections in Spiti Valley: Balini, Krystyn and Torti, 1998; Krystyn et al., 2004) is consistent with that of the Prati di Stuores/ Stuores Wiesen. 


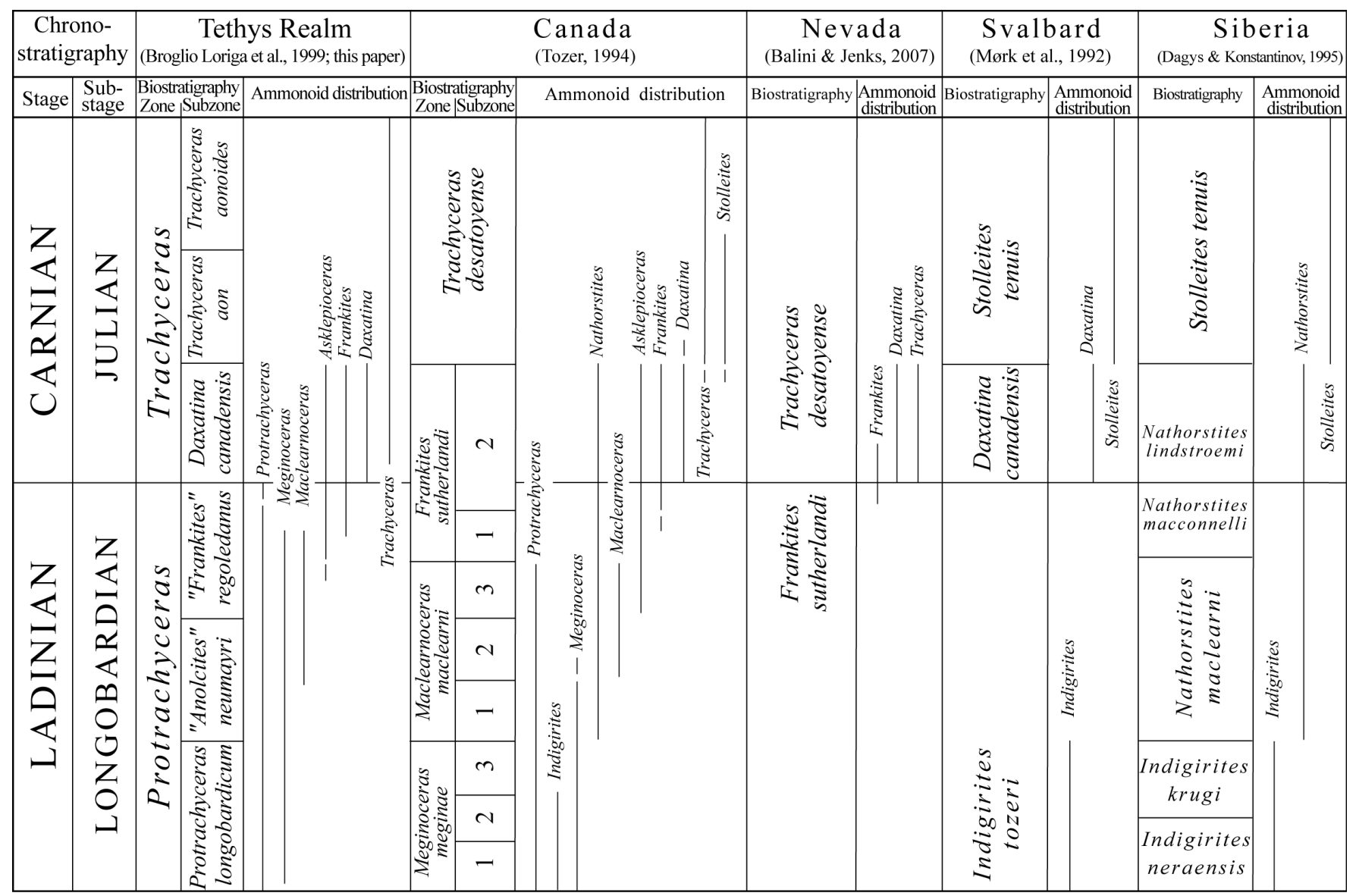

Figure 11. Bio- chronostratigraphic correlations between low, middle and high paleolatitude domains.

\section{Final comments}

The GSSP for the base of the Carnian Stage as defined by the first appearance of ammonoid Daxatina (Daxatina canadensis in bed SW4 of the Stuores Wiesen section) provides an excellent opportunity for trans-Panthalassa correlation between low to middle-high paleolatitude domains. This is made possible by the global distribution of some ammonoid species comprised in the canadensis Subzone. On the other hand, the co-appearance of genera Daxatina and Trachycers allows the historical definition of the base of the Carnian to be preserved. The appearance of Paragondolella polygnathiformis (a single specimen collected) a few centimeters above the GSSP boundary further enhances correlation based on conodont biostratigraphy. Well-documented palynomorph assemblages from the stratotype section allow correlation between marine and terrestrial depositional settings. Based on the available geochronologic data the Ladinian-Carnian boundary is estimated at ca. $237 \mathrm{Ma}$. The GSSP boundary falls near the base of S2n magnetozone, close to the beginning of the regressive trend (HST) associated with the Car 1 Depositional Sequence.

All these data tend to support a reliable and lasting chronostratigraphic definition of the Ladinian-Carnian boundary.

\section{Acknowledgements}

We wish to thank all authors who contributed to the original GSSP proposal (Broglio Loriga et al., 1998, 1999), including those who do not appear as authors of this paper. Some are no longer with us and we wish to remember them with love: Carmela Broglio Loriga, Vittorio De Zanche and Claudio Neri. Special gratitude is extended to $\mathbf{M}$. Balini, M. Gaetani and M. Orchard for useful discussion. We are also grateful to Rachele Andreetta, Fabrizio Tagliavini and Damiano Maragna for assistance in the field. The manuscript benefited greatly from the comments and suggestions of G.V.R. Prasad and J.G. Ogg.

\section{References}

Aberhan, M., 1994, Guild-structure and evolution of Mesozoic benthic shelf communities: Palaios, v. 9, pp. 516-545.

Balini, M., 2008, Discovery of Upper Ladinian ammonoids at the type locality of the Lower Carnian Desatoyense Zone (South Canyon, New Pass Range, Nevada): J. Paleont., v. 82/1, pp. 162-168.

Balini, M., and Jenks, J.F., 2007, The Trachyceratidae from South Canyon (Central Nevada): record, taxonomic problems and stratigraphic significance for the definition of the Ladinian-Carnian boundary: New Mex. Mus. Nat. Hist. \& Sci. Bull., v. 41, pp. 14-22.

Balini, M., Jenks, J.F., McRoberts, C.A., and Orchard, M.J., 2007, The Ladinian-Carnian boundary succession at South Canyon (New Pass Range, Central Nevada): New Mex. Mus. Nat. Hist. \& Sci. Bull., v. 40, pp. 127-138.

Balini, M., Krystyn, L., and Torti, V., 1998, In search of the Ladinian-Carnian boundary: perspectives from Spiti (Tethys Himalaya): Albertiana, v. 21, pp. 26-32.

Bizzarini, F., 1993, Microfossili al limite Ladinico-Carnico nella Successione dei Prati di Stuores (Dolomiti Orientali): Ann. Musei Civici, sez. Arch. St. Sci. Nat., v. 8, pp. 141-168.

Böhm, J., 1903, Über die obertriadische Fauna der Bäreninsel: K. Svenska Veten.-Akad. Handl., v. 37/3, pp. 2-76. 
Böhm, J., 1904, Über Nathorstites und Dawsonites aus der arktischen Trias: Zeitschr. Deutsch. Geol. Gesell., v. 56, pp. 96-97.

Bosellini, A., Gianolla, P., and Stefani, M., 2003, Geology of the Dolomites: Episodes, v. 26, pp. 181-185.

Brack, P., Mundil, R., Oberli, F., Meier, M., and Rieber, H., 1996, Biostratigraphic and radiometric age data question the Milankovitch characteristics of the Latemar cycles (Southern Alps, Italy): Geology, v. 24, n. 4, pp. 371-375.

Brack, P., Mundil, R., Oberli, F., Meier, M., and Rieber, H., 1997, Biostratigraphic and radiometric age data question the Milankovitch characteristics of the Latemar cycles (Southern Alps, Italy). Reply: Geology, v. 25, n. 5, pp. 471-472.

Brack, P., and Rieber, H., 1993, Towards a better definition of the Anisian/ Ladinian boundary: new biostratigraphic data and correlations of boundary sections from the Southern Alps: Ecl. geol. Helv., v. 86/2, pp. 415-527.

Brack, P., Rieber, H., and Urlichs, M., 1999, Pelagic succession in the Southern Alps and their correlation with the Germanic Middle Triassic: Zbl. Geol. Paläont., v. 1998/7-8, pp. 853-876.

Brack, P., Rieber, H., Nicora, A., and Mundil, R., 2005, The Global boundary Stratotype Section and Point (GSSP) of the Ladinian Stage (Middle Triassic) at Bagolino (Southern Alps, Northern Italy) and its implications for the Triassic time scale: Episodes, v. 28/4, pp. 233-244.

Brandner, R., 1984, Meeresspiegelschwankungen und Tektonik in der Trias der NW Tethys: Jahrb. Geol. Bundensanst., v. 126, pp. 287-325.

Broglio Loriga, C., Cirilli ,S., De Zanche, V., di Bari, D., Gianolla, P., Laghi, M.F., Lowrie, W., Manfrin, S., Mastandrea, A., Mietto, P., Muttoni, C., Neri, C., Posenato, C., Rechichi, M.C., Rettori, R., and Roghi, G., 1999, The Prati di Stuores/Stuores Wiesen Section (Dolomites, Italy): a candidate Global Stratotype Section and Point for the base of the Carnian stage: Riv. Ital. Paleont. Strat., v. 105/1, pp. 37-78.

Broglio Loriga, C., Cirilli, S., De Zanche, V., di Bari, D., Gianolla, P., Laghi, M.F., Lowrie, W., Manfrin, S., Mastandrea, A., Mietto, P., Muttoni, C., Neri, C., Posenato, C., Rechichi, M.C., Rettori, R., and Roghi, G., 1998, A GSSP candidate for the Ladinian/Carnian boundary: the Prati di Stuores/ Stuores Wiesen section (Dolomites, Italy): Albertiana, v. 21, pp. 2-18.

Brühwiler, T., Hochuli, P.A., Mundil, R., Schatz, W., and Brack, P., 2007, Bio- and chronostratigraphy of the Middle Triassic Reifling Formation of the westernmost Northern Calcareous Alps: Swiss. J. Geosci., v. 100, pp. 443-455.

Castellarin, A., and Cantelli, L., 2000, Neo-alpine evolution of the Southern Eastern Alps: Journal of Geodynamics, v. 30, pp. 251-274.

Catuneanu, O., Abreu, V., Bhattacharya, J.P., Blum, M.D., Dalrymple, R.W., Eriksson, P.G., Fielding, C.R., Fisher, W.L., Galloway, W.E., Gibling, M.R., Giles, K.A., Holbrook, J.M., Jordan, R., Kendall, C.G.St.C., Macurda, B., Martinsen, O.J., Miall, A.D., Neal, J.E., Nummedal, D., Pomar, L., Posamentier, H.W., Pratt, B.R., Sarg, J.F., Shanley, K.W., Steel, R.J., Strasser, A., Tucker, M.E., and Winker, C., 2009, Towards the standardization of sequence stratigraphy: Earth-Sci. Rev., v. 92, pp. 133.

Dagys, A.S., and Konstantinov, A.G., 1995, New Zonation Scheme of the Ladinian Stage for Northeastern Asia: Stratigraphy and Geological Correlation, v. 3, pp. 314-320, translated from Stratigrafiya Geologicheskaya Korrelyatsiya, v. 3, pp. 121-127.

De Zanche, V., and Gianolla, P., 1995, Litostratigrafia al limite LadinicoCarnico (Sudalpino orientale): Ann. Univ. Ferrara, Sci. Terra, v. 5(suppl.), pp. 41-48.

De Zanche, V., Gianolla, P., Mietto, P., Siorpaes, C., and Vail, P.R., 1993, Triassic sequence stratigraphy in the Dolomites (Italy): Mem. Sc. Geol., v. 45 , pp. 1-27.

Doglioni, C., 1987, Tectonics of the Dolomites (Southern Alps - NE Italy): J. Struct. Geol., v. 9, pp. 181-193.

Fisher, M.J., 1972, The Triassic palynoflora succession in England. Geosci. \& Man, v. 4, pp. 101-109.

Fisher, M.J., and Dunay, R.E., 1984, Palynology of the Petrified Forest Member of the Chinle Formation (Upper Triassic), Arizona, U.S.A.: Pollen et Spores, v. 26/2, pp. 241-284.

Fowell, S.J., Cornet, B., and Olsen, P.E., 1994, Geologically rapid Late Triassic extinctions: Palynological evidence from the Newark Supergroup: Geol. Soc. Am. Sp. Pap., v. 288, pp. 197-206.

Furin, S., Preto, N., Rigo, M., Roghi, G., Gianolla, P., Crowley, J.L., and Bowring, S.A., 2006, High-precision U-Pb zircon age from the Triassic of Italy: Implications for the Triassic time scale and the Carnian origin of calcareous nannoplankton and dinosaurs: Geology, v. 34, pp. 1009-1012.

Fürsich, F.T., and Wendt, J., 1977, Biostratinomy and palaeoecology of the Cassian Formation (Triassic) of the Southern Alps: Palaeogeogr., Palaeoclim., Palaeoecol., v. 22, pp. 257-323.

Gaetani, M., 1995, Criteri per la definizione della base del Piano Carnico: Ann. Univ. Ferrara, Sci. Terra, v. 5(suppl.), pp. 9-12.

Gallet, Y., Krystyn, L., and Besse, J., 1998, Upper Anisian to lower Carnian magnetostratigraphy from the Northern Calcareous Alps (Austria): Journal Geophysical Research, v. 103, pp. 605-621.

Gallet, Y., Krystyn, L., Besse, J., and Marcoux, J., 2003, Improving the Upper Triassic numerical time scale from cross-correlation between Tethyan marine sections and the continental Newark basin sequence: Earth Planetary Science Letters, v. 212, pp. 255-261.

Gianolla, P., De Zanche, V., and Mietto, P., 1998, Triassic Sequence Stratigraphy in the Southern Alps (Northern Italy), in de Graciansky, P.C., Jacquin T., and Vail, P.R. (eds) - Mesozoic and Cenozoic Sequence Stratigraphy of European Basins: S.E.P.M. Spec. Publ., v. 60, pp. 719747.

Gianolla, P., Micheletti, C., Panizza, M., and Viola, F., 2009, Nomination of the Dolomites for Inscription on the World Natural Heritage List Unesco: http://whc.unesco.org/en/list/1237/documents/

Hardenbol, J., Thierry, J., Farley, M.B., Jacquin, T., de Graciansky, P.C., and Vail, P.R., 1998, Mesozoic and Cenozoic sequence chronostratigraphic framework of European basins. In: P.C. de Graciansky, J. Hardenbol, T. Jacquin, P.R. Vail and D. Ulmer-Scholle (Eds.): Mesozoic and Cenozoic sequence stratigraphy of European basins: SEPM Special Publication, v. 60 , pp. $3-13$.

Hochuli, P.H., and Frank, S.M., 2000, Palynology (dinoflagellate cysts, sporepollen) and stratigraphy of the Lower Carnian Raibl Group in the Eastern Swiss Alps: Eclogae geol. Helv., v. 93, pp. 429-443.

Hongfu, Y, Kexin, Z, Jinnan, T, Zunyi, Y, and Shunbao, W., 2001, The Global Stratotype Section and Point (GSSP) of the Permian-Triassic Boundary: Episodes, v. 24, pp. 102-114.

Hounslow, M.W., and Muttoni, G., 2010, The geomagnetic polarity timescale for the Triassic: linkage to stage boundary definitions, in, Lucas, S.G. (ed.), The Triassic Timescale: Geol. Soc. London, Spec. Publ. 334, pp. 61-102.

Ichikawa, K., 1958, Zur Taxonomie und Phylogenie der triadischen "Pteriidae" (Lamellibranch), mit besonderer Berücksichtigung der Gattungen Claraia, Eumorphotis, Oxitoma und Monotis: Palaeontographica A, v. 111, pp. 131-212.

Jenks, J.F., Spielmann J.A., and Lucas, S.G., 2007, Triassic Ammonoids. a photographic journey: New Mex. Mus. Nat. Hist. \& Sci. Bull., v. 40, pp. 33-79.

Johnston, F.N., 1941, Trias at New Pass, Nevada (New Lower Karnic Ammonoids): J. Paleont., v. 15/5, pp. 447-491.

Klipstein, A.v., 1845, Beiträge zur geologischen Kenntniss der östlichen Alpen: Mitt. Gebiete Geol. Paläont., v. 1(1843-1845), pp. 1-311.

Korte, C., Kozur, H.W., and Veizer, J., 2005, $\delta^{13} \mathrm{C}$ and $\delta^{18} \mathrm{O}$ values of Triassic brachiopods and carbonate rocks as proxies for coeval seawater and palaeotemperature: Palaeogeogr., Palaeoclim., Palaeoecol., v. 226, pp. 287-306.

Kovács, S., 1983, On the evolution of excelsa-stock in the Upper LadinianCarnian (Conodonta, genus Gondolella, Triassic): Schriftenr. Erdwiss. Komm. Österr. Akad. Wiss., v. 5, pp. 107-120.

Kovács, S., Krystyn, L., Szabò, S., Dosztàly, L., and Budai T., 1991, The Ladinian/Carnian boundary in the Balaton Upland, Hungary: Symp. Trias. Strat. Abstr. Booklet, Lausanne, p. 39.

Kozur, H., 1980, Revision der Conodontenzonierung der Mittel- und Obertrias des tethyalen Faunenreichs: Geol. Paläont. Mitt. Innsbruck, v. 10, pp. 79-173.

Kozur, H., 1989, The Taxonomy of the Gondolellid Conodonts in the Permian and Triassic: Courier Forsch. Inst. Senckenberg, v. 117, pp. 409-469.

Kozur, H.W., and Weems, R.E., 2007, Upper Triassic conchostracan biostratigraphy of the continental rift basins of the eastern North America: its importance for correlating Newark supergroup events with the Germanic Basin and the International Geologic Time Scale, in Lucas, S.G., and Spielmann, J.A., eds., The Global Triassic: New Mex. Mus. Nat. Hist. \& Sci. Bull., v. 41, pp. 137-188.

Krystyn, L., 1983, Das Epidaurus-Profil (Griechenland) - ein Beitrag zur Conodonten-Standardzonierung des tethyalen Ladin und Unterkarn: 
Schriftenr. Erdwiss. Komm. Österr. Akad. Wiss. v. 5, pp. 231-258.

Krystyn, L., Balini, M., and Nicora, A., 2004, Lower and Middle Triassic stage and substage boundaries in Spiti: Albertiana, suppl. v. 30, pp. 39-52.

Krystyn, L.,1978, Eine neue Zonengliederung im alpin-mediterranen Unterkarn: Schriftenr. Erdwiss. Komm. Österr. Akad. Wiss., v. 4, pp. 37-75.

Jaffey, A. H., Flynn, K. F., Glendenin, L. E., Bentley, W. C., and Essling, A. M., 1971, Precision Measurement of Half-Lives and Specific Activities of ${ }^{235} \mathrm{U}$ and ${ }^{238} \mathrm{U}$ : Physical Review C, v. 4, pp. 1889-1906.

Laube, G.C., 1869, Die Fauna der Schichten von St. Cassian. Ein Beitrag zur Paläontologie der Alpinen Trias. V. Abtheilung. Cephalopoden. Schlusswort: Denkschr. Kais. Akad. Wiss., Math.-naturwiss. Cl., v. 30, pp. $49-105$.

Litwin, R.J., and Ash, S.R., 1993, Revision of the biostratigraphy of the Chatam Group (Upper Triassic), Deep River Basin, North Carolina, USA: Rev. Palaeobot. Palyn., v. 77, pp. 75-95.

Litwin, R.J., Traverse, A., and Ash, S.R., 1991, Preliminary palynological zonation of the Chinle Formation, southwestern U.S.A., and its correlation to the Newark Supergroup (eastern U.S.A.): Rev. Palaeobot. Palyn., v. 68 , pp. $269-287$.

Machel, H.G., 2001, Bacterial and thermochemical sulfate reduction in diagenetic settings - old and new insights: Sed. Geol., v. 140, pp. 143175.

Manco, S., Mietto, P., Nicora, A., Preto, N., Rigo, M., and Tognon, M., 2004, Conodont fauna at the Ladinian/Carnian boundary interval in the Southern Alps: Albertiana, suppl. v. 30, p. 9.

Marshall, J.D., 1992, Climatic and oceanographic isotopic signals from the carbonate rock record and their preservation: Geol. Mag., v. 129, pp. 151-162.

Martin, G.C., 1926, The Mesozoic Stratigraphy of Alaska: U.S. Geol. Surv. Bull., v. 776, pp. 1-489.

Masetti, D., Neri, C., and Bosellini, A., 1991, Deep-water asymmetric cycles and progradation of carbonate platforms governed by high frequency eustatic oscillation (Triassic of the Dolomites): Geology, v. 19, pp. 336339.

Mattinson, J. M., 2005, Zircon U/Pb chemical abrasion (CA-TIMS) method; combined annealing and multi-step partial dissolution analysis for improved precision and accuracy of zircon ages: Chemical Geology, v. 220 , pp. $47-66$

Mazza, M., Furin, S., Spötl, C., and Rigo, M., 2010, Generic turnovers of Carnian/Norian conodonts: climatic control or competition? Palaeogeogr., Palaeoclim., Palaeoecol., v. 290, pp. 120-137.

Mazza M., Cau A., and Rigo M., 2012, Application of numerical cladistic analyses to the Carnian-Norian conodonts: a new approach for phylogenetic interpretations. Journal of Systematic Palaeontology, accepted, DOI: 10.1080/14772019.2011.573584.

McRoberts, C.A., 1993, Systematics and biostratigraphy of halobiid Bivalves from the Martin Bridge Formation (Upper Triassic), Northeast Oregon: J. Paleont., v. 67(2), pp. 198-210.

McRoberts, C.A., 2000, A primitive Halobia (Bivalvia: halobioidea) from the Triassic of Northeast British Columbia: J. Paleont., v. 74(4), pp. 599603.

Mietto, P., Andreetta, R., Broglio Loriga, C., Buratti, N., Cirilli, S., De Zanche, V., Furin, S., Gianolla, P., Manfrin, S., Muttoni, G., Neri, C., Nicora A., Posenato, R., Preto, N., Rigo M., Roghi, G., and Spötl, C., 2007a, A Candidate Of The Global Boundary Stratotype Section And Point For The Base Of The Carnian Stage (Upper Triassic): GSSP at the base of the canadensis Subzone (FAD of Daxatina) in the Prati di Stuores/Stuores Wiesen section (Southern Alps, NE Italy): Albertiana, v. 36, pp. 78-97.

Mietto, P., Buratti, N., Cirilli, S., De Zanche, V., Gianolla, P., Manfrin, S., Nicora, A., Preto, N., Rigo, M., and Roghi, G., 2007b, New constraints for the Ladinian-Carnian boundary in the Southern Alps: suggestions for global correlation: New Mex. Mus. Nat. Hist. \& Sci. Bull., v. 41, pp. 275-281.

Mietto, P., and Manfrin, S., 1995a, A high resolution Middle Triassic ammonoid standard scale in the Tethys Realm. A preliminary report: Bull. Soc. Géol. France, v. 1995/5, pp. 539-563.

Mietto, P., and Manfrin, S., 1995b, La successione delle faune ad ammonoidi al limite Ladinico-Carnico (Sudalpino, Italia): Ann. Univ. Ferrara, Sci. Terra, v. 5(suppl.), pp. 13-35.

Mietto, P., and Manfrin, S., 1999, A Debate on the Ladinian-Carnian Boundary. Albertiana, v. 22, pp. 23-27, Münster.

Mietto, P., Manfrin, S., Preto, N., and Gianolla, P., 2008, Selected ammonoid fauna from Prati di Stuores/Stuores Wiesen and related sections across the Ladinian-Carnian boundary (Southern Alps, Italy): Riv. It. Paleont. Strat., v. $114 / 3$, pp. 377-429.

Mojsisovics, E.M. von, 1879, Die Dolomit-Riffe von Südtirol und Venetien. Beiträge zur Bildungsgeschichte der Alpen: A. Hölder, Wien, 552 pp.

Mojsisovics, E.M. von, 1882, Die Cephalopoden der mediterranen Triasprovinz: Abh. K. K. Geol. Reichsanst., v. 10, pp. 1-332.

Mørk, A., Vigran, J.O., Korchinskaya, M.V., Pchelina, T.M., Fefilova, L.A., Vavilov, M.N., and Weitschat, W., 1992, Triassic rocks in Svalbard, the Arctic Soviet islands and the Barents Shelf, bearing on their correlations, in Vorrent T.O., Bergsager E., Dahl-Stamnes Ø.A., Holter E., Johansen B., Lie E. and Lund T.B. (eds), Arctic Geology and Petroleum Potential: NPF Spec. Publ., v. 2, pp. 457-479.

Mostler, H., and Scheuring, B.W., 1974, Mikrofloren aus dem Langobard und Cordevol der Nördlichen Kalkalpen und das Problem des Beginns der Keupersedimentation im Germanischen Raum: Geol. Paläontol. Mitt. Innsbruck, v. 4, pp. 1-35.

Mundil, R., Brack, P., Meier, M., Rieber, H., and Oberli, F., 1996, High resolution U-Pb dating of middle Triassic volcaniclastics: time-scale calibration and verification of tuning parameters for carbonate sedimentation: Earth Planet. Sci. Lett., v. 141, pp. 137-151.

Mundil, R., Palfy, J., Renne, P.R., and Brack, P., 2010, The Triassic timescale: new constraints and a review of geochronological data, in, Lucas, S.G. (ed.), The Triassic Timescale: Geol. Soc. London, Spec. Publ., no. 334, pp. 41-60.

Münster, G.G. von, 1834, Über das Kalkmergel-Lager von St. Cassian in Tyrol und die darin vorkommenden Ceratiten: N. Jb. Miner. Geogn. Geol. Petrefactenk., v. 1834, pp. 1-15.

Muttoni, G., Kent, D.V., Olsen, P.E., Di Stefano, P., Lowrie, W., Bernasconi, S.M., and Hernández, F.M., 2004, Tethyan magnetostratigraphy from Pizzo Mondello (Sicily) and correlation to the Late Triassic Newark astrochronological polarity time scale: GSA Bull., v. 116, pp. 1043-1058.

Neri, C., and Stefani, M., 1998, Sintesi cronostratigrafica e sequenziale dell'evoluzione permiana superiore e triassica delle Dolomiti: Mem. Soc. Geol. It., v. 53, pp. 417-463.

Ogilvie, M.M., 1893, Contributions to the Geology of the Wengen and St. Cassian Strata in the Southern Tyrol: Quart. J. Geol. Soc., v. 49, pp. 1-78.

Ogilvie-Gordon, M.M., 1900, On the Fauna of the Upper Cassian Zone in Falzarego Valley, South Tyrol: Geol. Mag., n.s. IV, v. 7, pp. 337-349.

Ogilvie-Gordon, M.M., 1929, Geologie des Gebietes von Pieve (Buchenstein), St. Cassian und Cortina d'Ampezzo: Jb. Geol. Bundesanst., v. 79, pp. $357-424$.

Pisa, G., Castellarin, A., Lucchini, F., Rossi, P.L., Simboli, G., Bosellini, A., and Sommavilla, E., 1980, Middle Triassic magmatism in Southern Alps I: a review of general data in the Dolomites: Riv. Ital. Paleont. Strat., v. 85 , pp. $1093-1110$.

Posamentier, H.W. and Allen, G.P., 1999, Siliciclastic sequence stratigraphy: concepts and applications. Concepts in Sedimentology and Paleontology, vol. 7. Society of Economic Paleontologists and Mineralogists (SEPM). $210 \mathrm{pp}$.

Posamentier, H.W., Jervey, M.T., and Vail, P.R., 1988, Eustatic controls on clastic deposition I - conceptual framework, in, C.K. Wilgus, B.S. Hastings, C.G.St.C. Kendall, H.W. Posamentier, C.A. Ross and J.C. Van Wagoner (eds.) Sea Level Changes - An Integrated Approach: Society of Economic Paleontologists and Mineralogists (SEPM) Special Publication, v. 42 , pp. $110-124$.

Preto, N., Spötl, C., and Guaiumi, C., 2009, Evaluation of bulk carbonate $\delta^{13} \mathrm{C}$ data from Triassic hemipelagites and the initial composition of carbonate mud: Sedimentology, v. 56, pp. 1329-1345.

Ramezani, J., Hoke, G. D., Fastovsky, D. E., Bowring, S. A., Therrien, F., Dworkin, S. I., Atchley, S. C., and Nordt, L. C., 2011, High-precision U$\mathrm{Pb}$ zircon geochronology of the Late Triassic Chinle Formation, Petrified Forest National Park (Arizona, USA): Temporal constraints on the early evolution of dinosaurs: Geological Society of America Bulletin, v. 123, pp. 2142-2159.

Richoz, S., Krystyn, L., and Spötl, C., 2007, First detailed carbon isotope curve through the Ladinian-Carnian boundary: The Weissenbach section (Austria): Albertiana, v. 36, pp. 98-101.

Rigo, M., Preto, N., Roghi, G., Tateo, F., and Mietto, P., 2007, A CCD rise in the Carnian (Upper Triassic) of western Tethys, deep-water equivalent of the Carnian Pluvial Event: Palaeogeogr., Palaeoclim., Palaeoecol., v. 246 , pp. $188-205$. 
Rigo, M., Preto, N., Franceschi, M., and Guaiumi, C., 2012. Stratigraphy of the Carnian-Norian Calcari con Selce Formation in the Lagonegro Basin, Southern Apennines: Riv. It. Paleont. Strat., v. 118/1, pp. 143-154.

Rogers, R.R., Swisher, C.C., III, Sereno, P.C., Monetta, A.M., Forster, C.A., and Martinez, R.N., 1993, The Ischigualasto tetrapod assemblage (Late Triassic, Argentina) and 40Ar/39Ar dating of dinosaur origins: Science, v. 260, pp. 794-797.

Roghi, G., 2004, Palynological investigations in the Carnian of Cave del Predil area (once Raibl, Julian Alps): Rev. Palaeob. Palynol., v. 132, pp. 1-35.

Rüffer, T., and Zühlke, R., 1995, Sequence stratigraphy and sea-level changes in the Early to Middle Triassic of the Alps: a global comparison. In: Haq, B.U. (Ed.), Sequence Stratigraphy and Depositional Response to Eustatic, Tectonic and Climatic Forcing. Kluwer, Amsterdam, pp. 161207.

Russo, F., Neri, C., Mastandrea, A., and Baracca, A., 1997, The mud mound nature of the Cassian platform margins of the Dolomites. A case history: the Cipit boulders from Punta Grohmann (Sasso Piatto Massif, Northern Italy): Facies, v.36, pp. 25-36.

Scheuring, B.W., 1970, Palynologische und palynostratigraphische Untersuchungen des Keupers im Bolchentunnel (Solothurner Jura): Schweiz. Paläontol. Abh., v. 88, pp. 2-119.

Schoene, B., Crowley, J.L., Condon, D.J., Schmitz, M.D., and Bowring, S.A., 2006, Reassessing the Uranium decay constants for geochronology using ID-TIMS U-Pb data: Geochim. et Cosmochim. Acta, v. 70, pp. 426-445.

Sloman, L.E., 1989, Triassic Shoshonites from the Dolomites, Northern Italy - Alkaline Arc Rocks in a Strike-Slip Setting: Jour. Geophys. Res., v. 94/ B4, pp. 4655-4666.

Spötl, C., and Vennemann, T.W., 2003, Continuous-flow isotope ratio mass spectrometric analysis of carbonate minerals: Rapid Communications in Mass Spectrometry, v. 17, pp. 1004-1006.

Spötl, C., 2011, Long-term performance of the Gasbench IRMS system for stable isotope analysis of carbonate microsamples: Rapid Communcations in Mass Spectrometry, v. 25, pp. 1683-1685.

Stefani, M., Furin, S., and Gianolla, P., 2010, The changing climate framework and depositional dynamics of Triassic carbonate platforms from the Dolomites: Palaeogeogr., Palaeoclim., Palaeoecol., v. 290, pp. 43-57.

Tozer, E.T., 1967, A standard for Triassic Time: Geol. Surv. Canada Bull., v. 156 , pp. 1-103.

Tozer, E.T., 1994, Canadian Triassic Ammonoid Faunas: Geol. Surv. Canada Bull., v. 467, pp. 1-663.

Urlichs, M., 1974, Zur Stratigraphie und Ammonitenfauna der Cassianer Schichten von Cassian (Dolomiten/Italien): Schriftenr. Erdwiss. Komm. Österr. Akad. Wiss., v. 2, pp. 207-222.

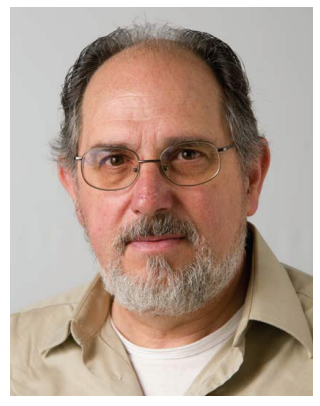

Paolo Mietto was a Professor in Stratigraphy at the University of Padova. His research activity was focused on the stratigraphic and paleontological problems related to the sedimentary cover of the Southern Alps. He has significantly contributed to the chronostratigraphic definition of the Anisian-Ladinian and Ladinian-Carnian boundaries, raising GSSP proposals.

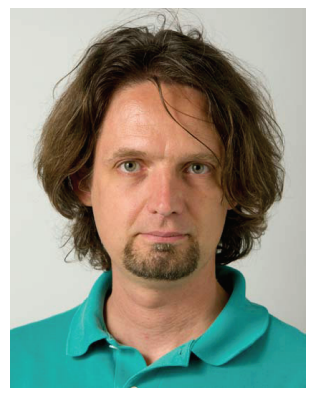

Nereo Preto is Assistant Professor at the Department of Geosciences, University of Padova, and Fellow of the Alexander von Humboldt foundation. His research focuses on Triassic paleoclimatology, carbonate geochemistry and high resolution physical stratigraphy.
Urlichs, M., 1977, Zur Alterstellung der Pachycardientuffe und der Unteren Cassianer Schichten in den Dolomiten (Italien): Mitt. Bayer. Staatsslg. Paläont. Hist. Geol., v. 17, pp. 15-25.

Urlichs, M., 1994, Trachyceras Laube 1869 (Ammonoidea) aus dem Unterkarn (Obertrias) der Dolomiten (Italien): Stuttg. Beitr. Naturk., ser. B, v. 217, pp. 1-55.

Van den Berg, J.J., 1987, Aspects of Middle and Late Triassic palynology. Palynological investigation in the Keuper (Upper Ladinian, Karnian, Norian and Rhaetian) and Lower Jurassic (Lias alfa1 + alfa2) of Franken, SE West-Germany: Stuifmail, v. 5, pp. 26-33.

Van der Eem, J.G.L.A., 1983, Aspects of Middle and Late Triassic Palynology. 6. Palynological investigations in the Ladinian and Lower Karnian of the Western Dolomites, Italy: Rev. Palaeobot. Palynol., v. 39, pp. 189300 .

Viel, G., 1979, Litostratigrafia ladinica: una revisione. Ricostruzione paleogeografia e paleostrutturale dell'area Dolomitico-Cadorina (Alpi Meridionali) - Parte II. Riv. It. Paleont. Strat., v. 85, pp. 85-125.

Veizer, J., Ala, D., Azmy, K., Bruckschen, P., Buhl, D., Bruhn, F., Carden, G.A.F., Diener, A., Ebneth, S., Goddris, Y., Jasper, T., Korte, C., Pawellek, F., Podlaha, O.G., and Strauss, H., $1999,{ }^{87} \mathrm{Sr} /{ }^{86} \mathrm{Sr}, \delta^{13} \mathrm{C}$ and $\delta^{18} \mathrm{O}$ evolution of Phanerozoic seawater: Chemical Geology, v. 161, pp. 59-88.

Visscher, H., and Brugman, W.A., 1981, Ranges of selected palynomorphs in the Alpine Triassic of Europe: Rev. Palaeobot. Palynol., v. 34, pp. 115128.

Waller, T.R., and Stanley, G.D.jr, 2005, Middle Triassic Pteriomorphian Bivalvia (Mollusca) from the New Pass Range, west-central Nevada: systematics, biostratigraphy, palaeoecology, and paleobiogeography: Jour. Paleont. v. 79, suppl.1, mem. 61, pp. 1-64.

Warrington, G., 1970, The stratigraphy and palaeontology of the 'Keuper' series of the central Midlands of England: Quart. Jour. Geol. Soc., v. 126 , pp. $183-223$.

Warrington, G., 1996, Chapter 20A, Triassic spores and pollen; in: Jansonius J. and McGregor, D.C., (ed.), Palynology: principles and applications: Am. Ass. Strat. Palynol. Found., v. 2, pp. 755-766.

Whiteaves, J.F., 1889, On some Fossils from the Triassic Rocks of British Columbia: Geol. Nat. Hist. Surv. Canada, Contrib. Canad. Palaeont., v. 1, pp. 127-149.

Wignall, P.B., 1994, Black shales. Geology and Geophysics Monographs: Oxford University Press, v. 30, pp. 1-130.

Wissmann, H.L, and Münster, G.G. von, 1841, Beiträge zur Geognosie und Petrefacten-Kunde des Südöstlichen Tirol's vorzüglich der Schichten von St. Cassian: Beitr. Petrefacten-Kunde, v. 4, pp. 1-152.

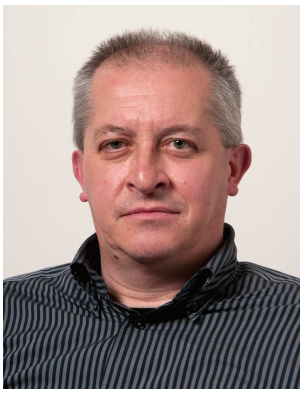

Stefano Manfrin is a collaborator of the Department of Geosciences at the University of Padova. He studies the taxonomic and chronostratigraphic problems of the Triassic ammonoids of the Southern Alps contributing also to the definition of the GSSP of the base of Ladinian and Carnian Stages, and realized a high-resolution ammonoid biostratigraphic scale for the Middle Triassic of the Tethys domain.

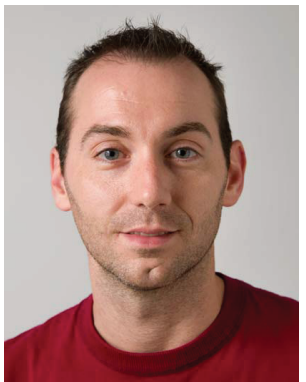

Manuel Rigo is Assistant Professor in Stratigraphy at the Department of Geosciences (University of Padova) and Associated Researcher of the Italian CNR. His research experience concerns mostly the study of Triassic stratigraphy, especially involving Triassic conodonts, as well as biostratigraphical and geochemical aspects. 